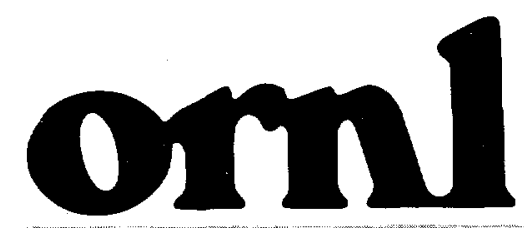

OAK RIDGE NATIONAL LABORATORY
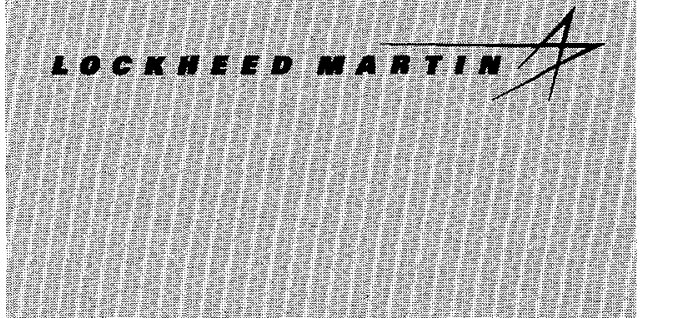

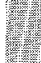

\section{II}

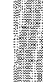

titis

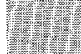

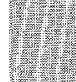

1)

(1)

$\sqrt{1}$

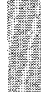

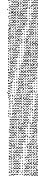

UANACED AND OPERATED BY

LOOKHEED WARTN ENERGY RESEARCH COAPORATION FORTHE UNTEO STATES

DEPARTIIVIT OF ENERGY

\title{
Radon Measurements at the Molten Salt Reactor Experiment (MSRE) Facility from August 1997 through April 1998
}

\author{
R. L. Coleman
}

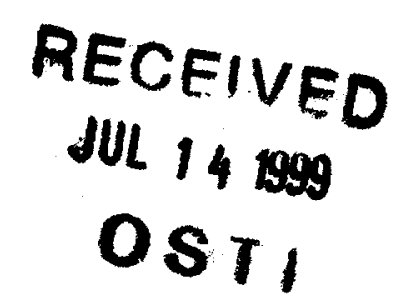


This report has been reproduced directly from the best available copy.

Available to DOE and DOE contractors from the Office of Scientific and Technical Information, P.O. Box 62, Oak Ridge, TN 37831; prices available from 423-576-8401.

Available to the public from the National Technical information Service, U.S. Department of Commerce, 5285 Port Royal Rd., Springfield, VA 22161.

This report was prepared as an account of work sponsored by an agency of the United States Government. Neither the United States Government nor any agency thereof, nor any of their employees, makes any warranty, express or implied, or assumes any legal liability or responsibility for the accuracy, completeness, or usefulness of any information, apparatus, product, or process disclosed, or represents that its use would not infringe privately owned rights. Reference herein to any specific commercial product, process, or service by trade name, trademark, manufacturer, or otherwise, does not necessarily constitute or imply its endorsement, recommendation, or favoring by the United States Government or any agency thereof. The views and opinions of authors expressed herein do not necessarily state or reflect those of the United States Government or any agency thereof. 


\section{DISCLAIMER}

Portions of this document may be illegible in electronic image products. Images are produced from the best available original document. 


\section{LIFE SCIENCES DIVISION}

\section{Radon Measurements at the Molten Salt Reactor Experiment (MSRE) Facility from August 1997 through April 1998}

R. L. Coleman

Date Issued—June 1999

Prepared for the MSRE Remediation Project, Bechtel Jacobs Company LLC

Oak Ridge, Tennessee 37831 under contract DE-AC05-98OR22700

Prepared by the

OAK RIDGE NATIONAL LABORATORY

Oak Ridge, Tennessee 37831-6285 managed by

LOCKHEED MARTWN ENERGY RESEARCH CORP. for the U.S. DEPARTMENT OF ENERGY under contract DE-AC05-96OR22464 


\section{Author Affiliation}

R. L. Coleman is a member of the Measurement Applications and Development Group, Assessment Technology Section, Life Sciences Division, OakRidge National Laboratory, Lockheed Martin Energy Research Corp., Oak Ridge, Tennessee. 


\section{CONTENTS}

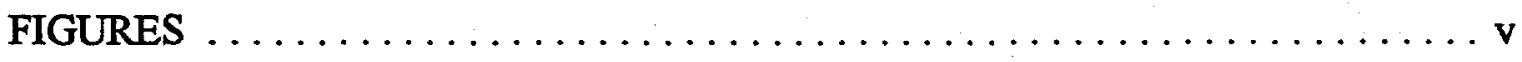

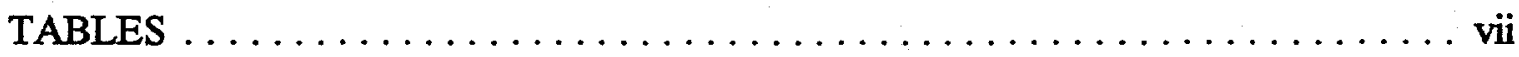

ACKNOWLEDGMENTS $\ldots \ldots \ldots \ldots \ldots \ldots \ldots \ldots \ldots \ldots \ldots \ldots \ldots \ldots \ldots \ldots$ ix

EXECUTIVE SUMMARY $\ldots \ldots \ldots \ldots \ldots \ldots \ldots \ldots \ldots \ldots \ldots \ldots \ldots \ldots$

1. INTRODUCTION $\ldots \ldots \ldots \ldots \ldots \ldots \ldots \ldots \ldots \ldots \ldots \ldots \ldots \ldots \ldots$

2. EQUTPMENT $\ldots \ldots \ldots \ldots \ldots \ldots \ldots \ldots \ldots \ldots \ldots \ldots \ldots \ldots \ldots \ldots \ldots \ldots \ldots$

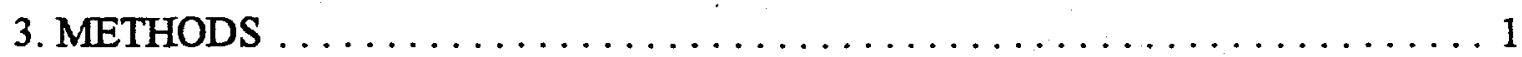

3.1 MEASUREMENT LOCATIONS $\ldots \ldots \ldots \ldots \ldots \ldots \ldots \ldots \ldots \ldots \ldots$

3.2 RADON DAUGHTER MEASUREMENTS $\ldots \ldots \ldots \ldots \ldots \ldots \ldots \ldots 2$

3.3 RADON MEASUREMENTS $\ldots \ldots \ldots \ldots \ldots \ldots \ldots \ldots \ldots \ldots \ldots \ldots \ldots \ldots$

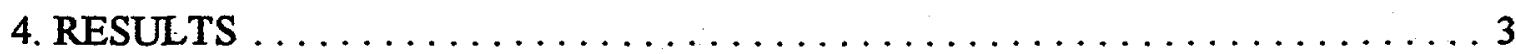

4.1 RADON DAUGHTER MEASUREMENT RESULTS $\ldots \ldots \ldots \ldots \ldots \ldots$

4.2 RADON MEASUREMENT RESULTS $\ldots \ldots \ldots \ldots \ldots \ldots \ldots \ldots$

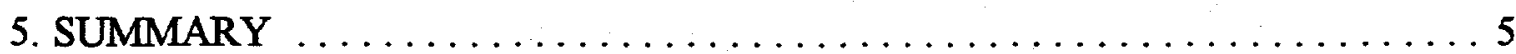

6. REFERENCES $\ldots \ldots \ldots \ldots \ldots \ldots \ldots \ldots \ldots \ldots \ldots \ldots \ldots \ldots$ 


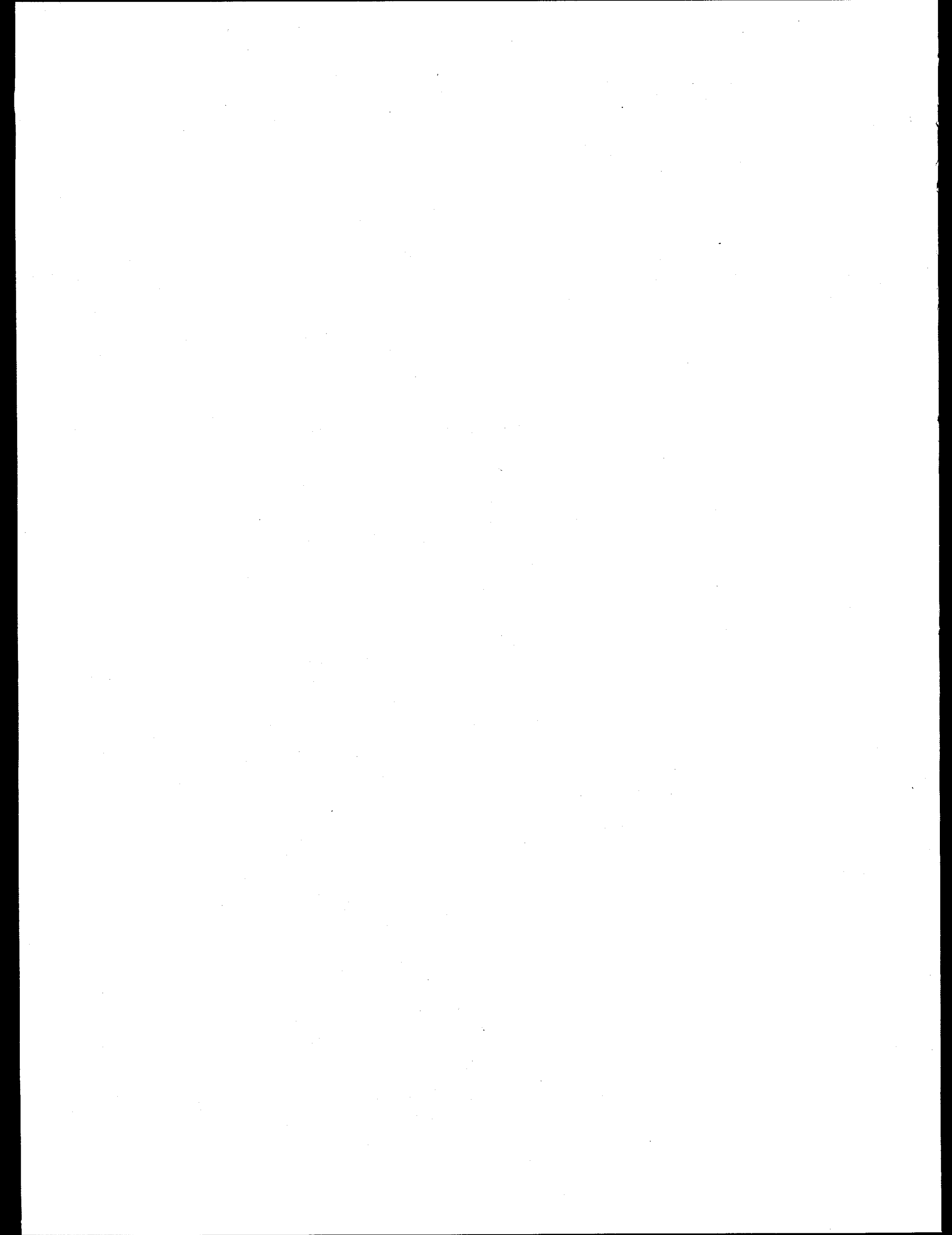




\section{FIGURES}

1 Main floor level of Building 7503 showing measurement locations BP1 through BP4

2 Concentrations of primary radon progeny measured at locations BP1. and BP2

3 Concentrations of primary radon progeny measured at locations BP3 and BP4

4 Plot of daily atmospheric pressure and of the differential pressure between the high bay and equipment cell (e.g., the cell pressure minus the high bay pressure)

5 Plot of percent standard measurement error (67\% confidence) versus measured concentration for ${ }^{212} \mathrm{~Pb}$ and ${ }^{212} \mathrm{Bi}$ (Th-B and Th-C)

6 Plot of percent standard measurement error ( $67 \%$ confidence) versus measured concentration for ${ }^{218} \mathrm{Po}$ and ${ }^{214} \mathrm{~Pb}$ (Ra-A and Ra-B)

7 Radon measurements in the pit above the equipment drain tank cell during November and December 1997

8 Radon measurements in the pit above the equipment drain tank cell during January and February 1998 14

9 Radon measurements in the vent house during April 1998 15 


\section{TABLES}

1 Measured concentrations of radon daughters in air at

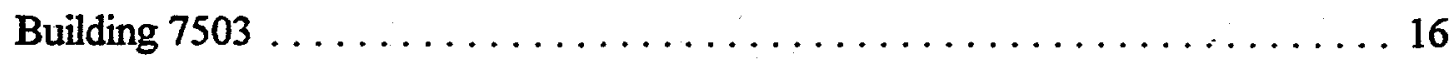

2 Ratio of the measured radon daughter working levels to the $\ldots \ldots \ldots \ldots 19$ derived air concentration (DAC) guide

3 Summary of radon and thoron progeny measurements at the MSRE facility 22 


\section{ACKNOWLEDGMENTS}

The author wishes to acknowledge the support, assistance, and interest of R. L. Faulkner, F. J. Peretz, J. M. Rushton, and R. M. Szozda at the MSRE. The author also acknowledges valuable technical assistance from M. E. Murray, editorial assistance from M. S. Uziel, and field measurement support by V. P. Patania and D. A. Roberts-all of the Life Sciences Division. 



\section{EXECUTIVE SUMMARY}

Planned remediation at the Oak Ridge National Laboratory (ORNL) Molten Salt Reactor Experiment (MSRE) facility created the need to measure ${ }^{220} \mathrm{Rn}$ and its progeny in air within work areas. Most of the original ${ }^{233} \mathrm{U}$ fuel material is still present in the process system at the facility and will eventually be removed as decommissioning progresses. A hazard associated with the ${ }^{233} \mathrm{U}$ material is the production of ${ }^{220} \mathrm{Rn}$ from the ${ }^{232} \mathrm{U}$ decay chain. Although ${ }^{232} \mathrm{U}$ is in ${ }^{233} \mathrm{U}$ material at a small mass fraction, it can equate to a significant activity level due to its short half-life. To illustrate the magnitudes of activity expected, consider the fuel material in the MSRE facility, which contains ${ }^{232} \mathrm{U}$ at a mass concentration of $160 \mathrm{ppm}$. After a period of about 13 years, the ${ }^{228} \mathrm{Th}$ activity would have equilibrated to about $3.5 \mathrm{Ci} / \mathrm{kg}$ of uranium. A kilogram of uranium would therefore be expected to produce ${ }^{220} \mathrm{Rn}$ at a rate of $1.3 \mathrm{E} 11$ atoms $/ \mathrm{s}$, or $4.4 \mathrm{E}-2 \mathrm{Ci} / \mathrm{s}$.

During the early phases of remedial investigations at the facility, it was noticed that air monitoring equipment would occasionally alarm. There were seven continuous air monitors installed for monitoring air quality in the facility for the presence of radionuclides. Some of these devices had sensors for alpha emitters while the remainder used beta-gamma detectors. The systems had modern measurement ability with integrated alarm functions for warning facility personnel to possible adverse air conditions. The monitors were installed to detect uranium emissions, fission and activation products as well as radioactive daughter products such as ${ }^{220} \mathrm{Rn}$ progeny. Whenever alarms were received, the instruments would be checked by health physics personnel to determine the source of the alarm. Sometimes the alarm was found to be due to equipment malfunction while at other times it was due to contamination on the filter paper. The filter paper would be removed and counted to evaluate the captured radionuclide. The initial gross alpha and beta-gamma counts, together with the short observed decay times, usually supported the conclusion that the source of the alarms was radon progeny. The frequency of alarms-several per week-however, resulted in the need to further understand the meaning of these alarms and the possible implications on personnel safety.

Follow-up analysis of samples collected from the monitors usually indicated that radon was the likely culprit, but it wasn't clear whether the progeny was from naturally occurring ${ }^{222} \mathrm{Rn}$ or from ${ }^{220} \mathrm{Rn}$ being produced by residual facility uranium. It was subsequently decided that an evaluation of radon progeny in the facility air would be performed-with particular emphasis placed on a baseline evaluation of ${ }^{220} \mathrm{Rn}$ daughters. During the assessment, a method was also developed for directly measuring both ${ }^{222} \mathrm{Rn}$ and ${ }^{220} \mathrm{Rn}$ using dual scintillation cells, and data were subsequently collected from two areas at the facility for supplemental information. By the end of the measurement period, data had been collected that quantified

${ }^{220} \mathrm{Rn},{ }^{222} \mathrm{Rn}$, and their progeny concentrations in the building air-primarily in the high-bay area of Building 7503 since it is directly adjacent to fuel storage areas. While direct radon measurements give accurate information about the fluctuation of air concentrations in an area, this information can only be used to infer occupational hazard when progeny-in-air ratios are 
known. Conversely, progeny data can be used directly to estimate occupational dose potential. This report provides the results of all radon and progeny measurements collected from August 1997 through April 1998 and compares them to Department of Energy occupational exposure guidelines for radon and its progeny.

The measurements indicated that ${ }^{220} \mathrm{Rn}$ was being emitted into parts of the facility from various sources of uranium during the measurement period. Areas believed to be primary contributors included the vent-house, the fuel drain tank cell, the reactor cell, and the fuel drain tank pit. The typical concentration of ${ }^{220} \mathrm{Rn}$ progeny in the drain tank pit during the study was $<1 \%$ of the derived air concentration (DAC) while the direct ${ }^{20} \mathrm{Rn}$ measurements in the same area indicated an average concentration of about $1.2 \mathrm{pCi} / \mathrm{L}$. A considerably higher ${ }^{220} \mathrm{Rn}$ concentration was observed in the vent house area with maximum levels of almost $200 \mathrm{pCi} / \mathrm{L}$; however, the progeny concentrations in this area were found to be low-with an average of $<1 \%$ of the DAC. The results therefore indicated that the air quality at the MSRE was not a health and safety concern for the workers performing remediation tasks, but that short term spikes in concentrations warranted follow-up monitoring.

It is expected that future remediation tasks could result in short term increases of ${ }^{220} \mathrm{Rn}$ in occupied work spaces. Work plans at the facility are being designed in a manner to control ${ }^{220} \mathrm{Rn}$ emissions through good engineering practices; however, direct monitoring for the isotope is expected to continue. The data presented in this report, together with future measurements, will allow trending analysis and impact assessments for both assuring and documenting the safety of personnel performing tasks within the MSRE facility. 


\section{INTRODUCTION}

Radon and radon daughter measurements were collected at the Molten Salt Reactor Experiment (MSRE) Building 7503 during the period of August 1997 through April 1998. The purpose of the measurements was to determine the concentrations of ${ }^{222} \mathrm{Rn}$ (radon), ${ }^{220} \mathrm{Rn}$ (thoron), and their progeny in the air at selected points in the building with emphasis on the characterization of ${ }^{220} \mathrm{Rn}$ and its daughters. The source of ${ }^{220} \mathrm{Rn}$ at the MSRE is ${ }^{232} \mathrm{U}$ in the fuel salt, which eventually produces ${ }^{220} \mathrm{Rn}$ through the ${ }^{228} \mathrm{Th}$ decay chain. This report documents the results for the measurements.

\section{EQUIPMENT}

Radon Daughter Measurements

- SAIC AVS-28A Carbon Vane Air Pumps

- EG\&G Model 7401 Alpha Spectrometer

- Oxford PCAP Multi-Channel Analyzer

- Gelman GN-4 Membrane Type Filters ( $0.8 \mu \mathrm{m}$ pore size)

\section{Radon Measurements}

- Pylon Model AB-5 with integrated high voltage, scalar, pump and photo-multiplier

- Pylon Model 300 A scintillation cell

- Campbell Scientific Model 2IX Data Logger

\section{METHODS}

Radon daughter samples were collected and analyzed by alpha spectrometry from four points within the high bay area and at one location in the vent house. In addition to these repeated measurements over time, grab samples were collected for daughter analysis at four other locations in the building. Direct radon measurements were collected over an extended period both in the pit above the equipment drain tank cell and in the vent house. These direct measurements were collected using flow through scintillation cells with the output recorded to a data logger.

\subsection{MEASUREMENT LOCATIONS}

With the exception of a few random measurements collected within Building 7503, the bulk of the measurements and samples were collected at the following locations-with each location being assigned a unique code for reference as indicated. 


\begin{tabular}{l|l} 
Code & \multicolumn{1}{|c}{ Description } \\
\hline BP1 & BAY AREA: SW corner of high bay on top of concrete shield material. \\
BP2 & BAY AREA: at fencing next to drain tank cell \\
BP3 & BAY AREA: next to the drum storage area at the NE corner of bay. \\
BP4 & $\begin{array}{l}\text { BAY AREA: inside of the pit above the equipment drain tank cell. Measurements were } \\
\text { collected near the south wall at } \sim 2 \mathrm{ft} \text { above the pit floor. } \\
\text { FH1 }\end{array}$ \\
FEN2 & $\begin{array}{l}\text { VENT HOUSE: about } 4 \text { feet inside of the entry door near the east wall of the room. } \\
\text { VENSE: near the center of the room . }\end{array}$
\end{tabular}

The measurement points located within the high bay area of Building 7503 are shown in Fig. 1 (p. 7).

\subsection{RADON DAUGHTER MEASUREMENTS}

Radon progeny isotopes were collected onto membrane filters using air pumps operating at a constant flow rate of $0.71 \mathrm{ft}^{3} / \mathrm{min}(20 \mathrm{~L} / \mathrm{min})$. The analysis consisted of performing three different measurements of the samples under vacuum - with the first count being performed within a few minutes of pump shutoff. The net results from the alpha spectrometry measurements were then used to calculate the radon, thoron, and actinon $\left.{ }^{219} \mathrm{Rn}\right)$ daughter concentrations in air by use of algorithms developed at ORNL (Kerr 1975; Kerr et al. 1978; Perdue et al. 1978; and Abdelrazek, M. M., 1989, Modification of the RAT3 Computer Program, internal report prepared for the Health and Safety Research Division, Oak Ridge Natl. Lab.).

Samples were collected for time periods ranging from 10 min up to as long as $\sim 21 / 2$ days with most sample times falling between 18 and 24 hours. For simplicity of reporting, these time intervals are referred to as grab, weekend, and overnight samples, respectively. The short, or grab, sample intervals were used primarily for measuring ${ }^{222} \mathrm{Rn}$ daughters while the overnight samples were selected for the best sensitivity of ${ }^{220} \mathrm{Rn}$ progeny. A single set of samples was collected over a weekend interval and was relevant to ${ }^{220} \mathrm{Rn}$ evaluation. A full weekend is too long for collecting a sample for ${ }^{220} \mathrm{Rn}$ daughters while maintaining a reasonable level of associated error, but this was done one time to check that nothing out of the ordinary was occurring during this time period. Most samples were collected overnight since the primary goal of this study was to characterize the thoron $\left({ }^{220} \mathrm{Rn}\right)$ progeny concentrations.

\subsection{RADON MEASUREMENTS}

Two scintillation cells were arranged in a serial configuration and the concentrations of ${ }^{222} \mathrm{Rn}$ and ${ }^{220} \mathrm{Rn}$ were determined by making use of the difference in half-life (3.8 days for ${ }^{222} \mathrm{Rn}$ and $55 \mathrm{sec}$ for ${ }^{220} \mathrm{Rn}$ ). A complete description of this measurement method is presented by Coleman (1999). 


\section{RESULTS}

\subsection{RADON DAUGHTER MEASUREMENT RESULTS}

The measured radon and thoron daughter concentrations are given in Table 1 (p. 16). Note that all measurements with relative errors greater than $100 \%$ were automatically excluded and flagged as such. With only a few exceptions, the observed concentrations were very low with the following isotope-specific comments being noted:

- The ${ }^{222} \mathrm{Rn}$ daughter concentrations ranged from $<0.05 \mathrm{pCi} / \mathrm{L}$ up to $\sim 0.5 \mathrm{pCi} / \mathrm{L}$ with the median observed concentration falling between 0.2 and $0.3 \mathrm{pCi} / \mathrm{L}$.

- The ${ }^{220} \mathrm{Rn}$ daughter concentrations ranged from $<0.005 \mathrm{pCi} / \mathrm{L}$ up to $\sim 0.8 \mathrm{pCi} / \mathrm{L}$ with most of the observed concentrations falling between 0.05 and $0.1 \mathrm{pCi} / \mathrm{L}$. Significant spikes in concentrations occurred for approximately a 1-week period starting around October 8 at location BP4-positioned in the pit above the drain tank cell.

The concentrations measured at each of the four primary locations are plotted as a function of the collection date in Figs. 2 and 3 (pp. 8 and 9). Note that all results are plotted regardless of the amount of error associated with the result. A plot of the daily atmospheric pressure and of the differential pressure between the high bay and the equipment cell during collection of the progeny samples is shown in Fig. 4 (p. 10) for comparison. No correlation between either of these pressure readings and the measured radon or thoron concentrations was noted.

The primary goal of the daughter measurement effort was to evaluate the ${ }^{220} \mathrm{Rn}$ progeny concentrations, therefore, most samples were collected overnight. The negative impact of this methodology was a decreased sensitivity and larger measurement errors for ${ }^{222} \mathrm{Rn}$ daughter concentrations. A plot of relative error versus observed concentration is given for each of the four primary radon progeny in Figs. 5 and 6 (pp. 11 and 12). A review of the figures indicates that the overnight measurement method allows the measurement of ${ }^{212} \mathrm{~Pb}(\mathrm{Th}-\mathrm{B})$ to within better than $10 \%$ relative error at concentrations as low as $0.02 \mathrm{pCi} / \mathrm{L}$ while the best that could be expected for ${ }^{214} \mathrm{~Pb}(\mathrm{Ra}-\mathrm{B})$ was $\pm 80 \%$ at concentrations of approximately $0.5 \mathrm{pCi} / \mathrm{L}$. For brief grab samples the opposite is true. Except at high concentrations, the ${ }^{212} \mathrm{~Pb}(\mathrm{Th}-\mathrm{B})$ would not be detected at all, but ${ }^{214} \mathrm{~Pb}(\mathrm{Ra}-\mathrm{B})$ could be detected to levels as low as $0.2 \mathrm{pCi} / \mathrm{L}$ with relative errors on the order of $\pm 40 \%$.

It is of interest to compare the observed radon daughter air concentrations to potential personnel dose. Occupational derived air concentration (DAC) limits for ${ }^{222} R n$ and ${ }^{220} R n$ progeny in air are listed by the Department of Energy (DOE 10 CFR 835) as:

${ }^{222} \mathrm{Rn}$ Progeny: $1 / 3$ Working Level (WL)

${ }^{220} \mathrm{Rn}$ Progeny: $1 \mathrm{WL}$

A working level is defined as any combination of short-lived radon daughters in $1 \mathrm{~L}$ of air that will result in the ultimate emission of $1.3 \times 10^{5} \mathrm{MeV}$ of alpha energy. In addition to these 
radon-specific guides, the DOE also lists occupational DAC limits for radionuclides in air assuming a $1 \mu \mathrm{m}$ AMAD (activity median aerodynamic diameter) particle distribution. Although the radon progeny $\left({ }^{212} \mathrm{~Pb},{ }^{212} \mathrm{Bi},{ }^{214} \mathrm{~Pb}\right.$, and $\left.{ }^{214} \mathrm{Bi}\right)$ are listed in this table of values, the radon-specific limits given in the table footnotes are the more restrictive and are appropriate for evaluating radon daughter exposure potential. The radon-specific DAC limits are based on recommendations given in ICRP Publication 32 (ICRP 1981) and Federal Guidance Report No. 11 (EPA 1988) and use dose modeling parameters specific to radon progeny in air. Considering the ICRP guidance, the DOE limits listed above correlate to an annual effective whole body dose equivalent limit of about 5 rem-assuming that a worker is exposed at this concentration for 2000 hours per year.

The measured working level concentrations were compared to the DOE DACs for each of the radon chains. In addition, a unity summation was performed by summing the ratio of the observed WL for each radon chain to the WL limit for that chain. The summed ratio will equal one when all daughters together result in a concentration equal to one DAC. Only samples showing positive results are included in these calculations. The computed ratios for each measurement is given in Table 2 (p. 19) and a summary of the results is presented in Table 3 (p. 22).

\subsection{RADON MEASUREMENT RESULTS}

Direct radon measurements were collected in the pit above the drain tank cell in the high bay area and also in the vent house adjacent to the south end of Building 7503. Measurements collected in the pit area are referenced as being measured at location BP4 and measurements collected in the vent house are referenced at location $\mathrm{FH} 2$.

The ${ }^{22} \mathrm{Rn}$ and ${ }^{220} \mathrm{Rn}$ concentration measurements at location BP4 were collected from late November 1997 through the end of February 1998. The results for these measurements are presented graphically in Figs. 7 and 8 (pp. 13 and 14). The measured concentrations at location FH2 were collected during April 1998 and the results are presented in Fig. 9 (p. 15).

Direct radon measurements in the pit above the drain tank cell (i.e., location BP4) indicated that ${ }^{222} \mathrm{Rn}$ concentrations remained relatively constant throughout the measurement period with a range from $\angle 0.5 \mathrm{pCi} / \mathrm{L}$ up to $3 \mathrm{pCi} / \mathrm{L}$. The average observed concentration in the pit area was $1.4 \mathrm{pCi} / \mathrm{L}$ with most values falling between 1 and $2 \mathrm{pCi} / \mathrm{L}$. A similar ${ }^{22} \mathrm{Rn}$ concentration was observed in the vent house at location $\mathrm{FH} 2$ and also remained relatively constant. The results ranged from $<1 \mathrm{pCi} / \mathrm{L}$ up to $6 \mathrm{pCi} / \mathrm{L}$ with an average concentration of $0.7 \mathrm{pCi} / \mathrm{L}$. Note that the highest reported concentrations of ${ }^{222} \mathrm{Rn}$ were observed during times when the concentration of ${ }^{220} \mathrm{Rn}$ was peaked. When using the two scintillation cell method, separation of detection signal for either isotope can be difficult when the other radionuclide is present at a much higher concentration due to slight uncertainty in the determination and use of a ${ }^{220} \mathrm{Rn}$ decay factor between the cells. Considering this, it is reasonable to assert that some portion of ${ }^{222} \mathrm{Rn}$ measurements could be attributed to signal cross-talk generated when ${ }^{220} \mathrm{Rn}$ is present at a high concentration. The same effect would be observed for ${ }^{220} \mathrm{Rn}$ results if the ratio of ${ }^{222} \mathrm{Rn}$ to ${ }^{220} \mathrm{Rn}$ was significantly large. 
Direct ${ }^{220} \mathrm{Rn}$ concentrations in the pit varied appreciably during November and December 1997 but stabilized to a constantly low or non-measurable level during January 1998 and remained this way through the remainder of the measurement period. The measured ${ }^{220} \mathrm{Rn}$ concentration during November and December ranged from $<0.5 \mathrm{pCi} / \mathrm{L}$ up to a single time maximum of about $30 \mathrm{pCi} / \mathrm{L}$. The average concentration during this time period was $2 \mathrm{pCi} / \mathrm{L}$. The measured ${ }^{220} \mathrm{Rn}$ concentration in the pit area during January and February ranged from $<0.5 \mathrm{pCi} / \mathrm{L}$ up to a single time maximum of about $20 \mathrm{pCi} / \mathrm{L}$. The average concentration during this time period was less than detectable. The measured ${ }^{220} \mathrm{Rn}$ concentration in the vent house during the April 1998 measurement series ranged from less than detectable up to $200 \mathrm{pCi} / \mathrm{L}$. The average concentration in the vent house was $18 \mathrm{pCi} / \mathrm{L}$. The lower limit of detection for ${ }^{20} \mathrm{Rn}$ during the collection of these measurements is estimated to be approximately $0.5 \mathrm{pCi} / \mathrm{L}$.

\section{SUMMARY}

From August 1997 through April 1998, radon and radon progeny measurements were collected at the Molten Salt Reactor Experiment (MSRE) facility at Oak Ridge National Laboratory. The purpose of the measurements was to determine the baseline concentrations of ${ }^{222} \mathrm{Rn}$ (radon), ${ }^{220} \mathrm{Rn}$ (thoron), and their progeny in the air at selected points with emphasis on the characterization of ${ }^{220} \mathrm{Rn}$ and its daughter products in the high bay area. The daughter product concentrations ranged from the equivalent of approximately 0.001 times the derived air concentration (DAC) of the isotope mixture up to 0.09 DAC, with the highest measurements occurring inside the pit above the equipment drain tank cell. Direct radon measurements in this area indicated a relatively constant ${ }^{222} \mathrm{Rn}$ concentration with an average value of $1.4 \mathrm{pCi} / \mathrm{L}$ and a ${ }^{20} \mathrm{Rn}$ concentration that fluctuated from $<1 \mathrm{pCi} / \mathrm{L}$ up to about $30 \mathrm{pCi} / \mathrm{L}$. Measurements were also collected inside the vent house adjacent to Building 7503. The progeny concentrations inside the room ranged from an equivalent of about $0.002 \mathrm{DAC}$ up to 0.01 DAC. The direct radon measurements in the vent house indicated a relatively constant ${ }^{222} \mathrm{Rn}$ concentration with an average value of $0.7 \mathrm{pCi} / \mathrm{L}$ while the ${ }^{220} \mathrm{Rn}$ concentration varied appreciably and ranged from $<0.5 \mathrm{pCi} / \mathrm{L}$ up to almost $200 \mathrm{pCi} / \mathrm{L}$ with an average concentration of $18 \mathrm{pCi} / \mathrm{L}$. 


\section{REFERENCES}

Code of Federal Regulations, Title 10, Part 835 (10 CFR 835). 1993. Occupational Radiation Protection; Final Rule, U. S. Department of Energy.

Coleman, R. L. 1999. A Method for Real Time Measurement of ${ }^{222} R n$ and ${ }^{220} R n$ Using Scintiallation Cells (Lucas Cells) (in preparation).

Environmental Protection Agency (EPA). 1988. Limiting Values of Radionuclide Intake and Air Concentration and Dose Conversion Factors for Inhalation, Submersion and Ingestion U. S. Environmental Protection Agency, Federal Guidance Report No. 11, EPA-520/1-88-020.

International Commission on Radiological Protection (ICRP). 1981 . Limits for Inhalation of Radon Daughters by Workers, ICRP Publication 32. Pergamon Press, New York

Kerr, G. D. 1975. Measurement of Radon Progeny Concentrations in Air by Alpha Particle Spectrometry, ORNL/TM-4924. Oak Ridge Natl. Lab., Oak Ridge, Tenn.

Kerr, G. D., M. T. Ryan, and P. T. Perdue. 1978. Measurement of Airborne Concentrations of ${ }^{220} R n$ Daughter Products by Alpha Particle Spectroscopy, pp. 61-75, Eleventh Midyear Topical Symposium, Health Physics Society, San Diego, Calif.

Perdue, P. T., R. W. Leggett, and F. F. Haywood. 1978. A Technique for Evaluating Airborne Concentrations of Daughters of Radon Isotopes, Natural Radiation Environment III, Houston, Texas.

Pylon Electronic Development Company, Ltd. 1989. Instruction Mamual for using Pylon Model 110A and 300A Lucas Cells with Pylon Model AB-5, Manual No. A900071. 


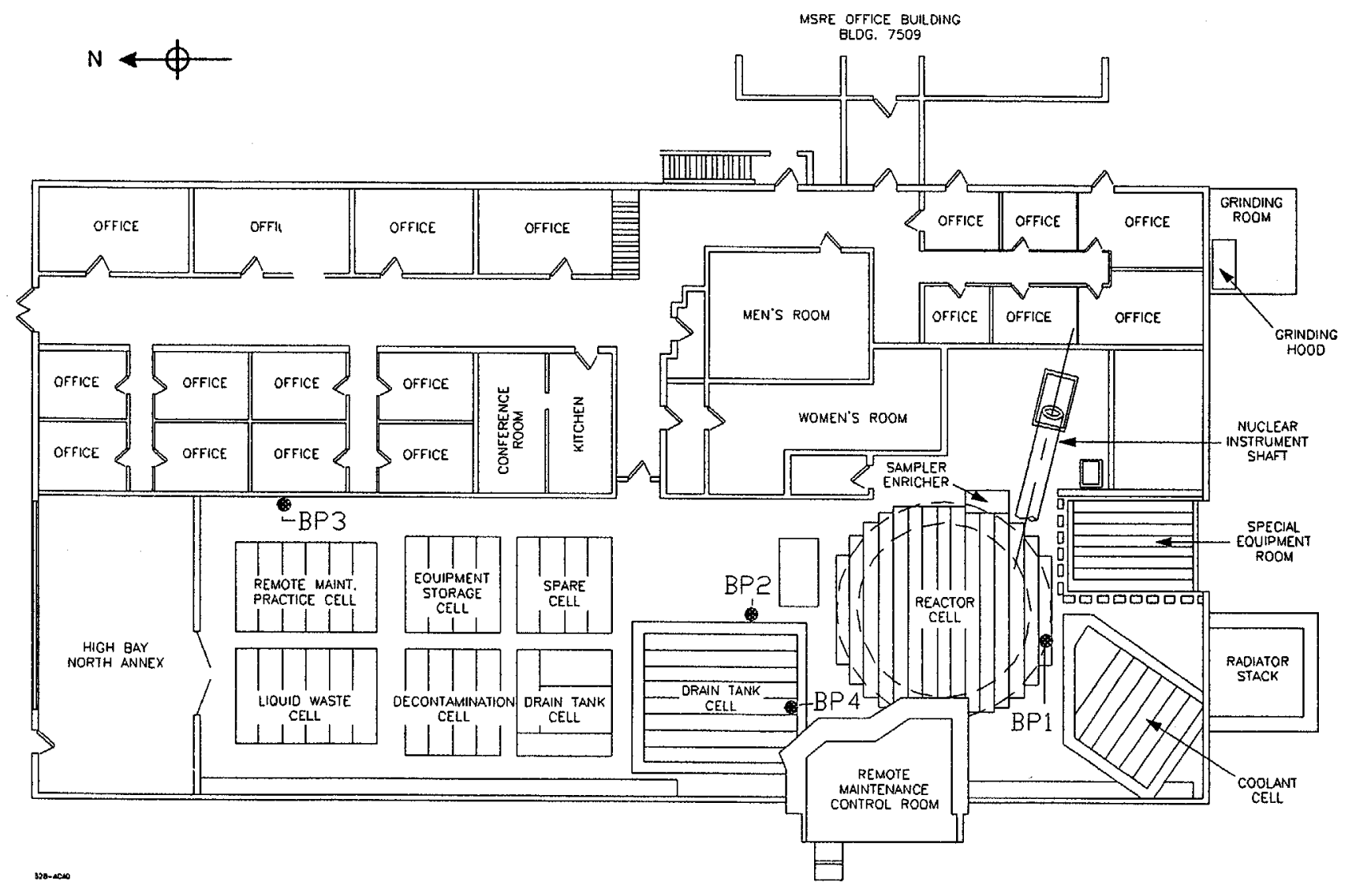

Fig. 1. Main floor level of Building 7503 showing measurement locations BP1 through BP4. 
Location BP1: SW Corner of Bay on Shield Blocks

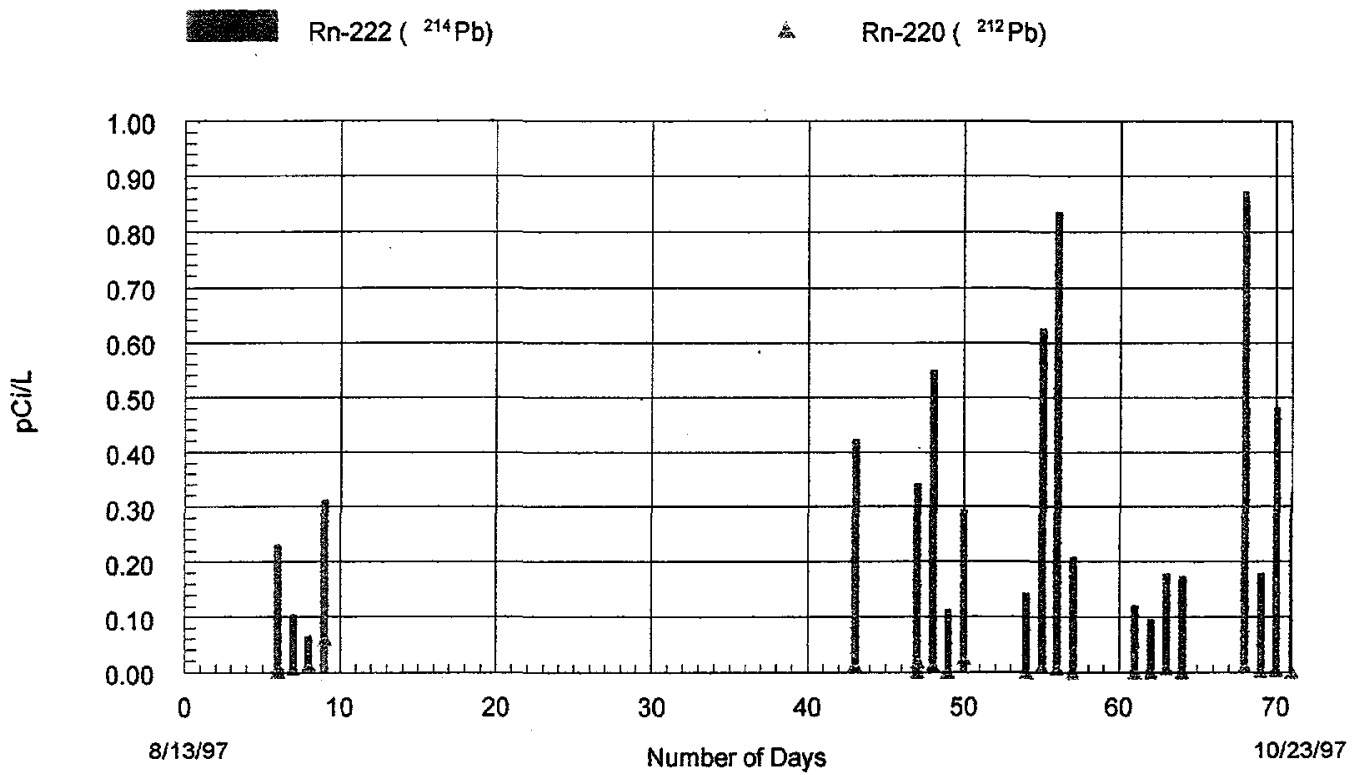

Location BP2: Near Equipment Storage Pit

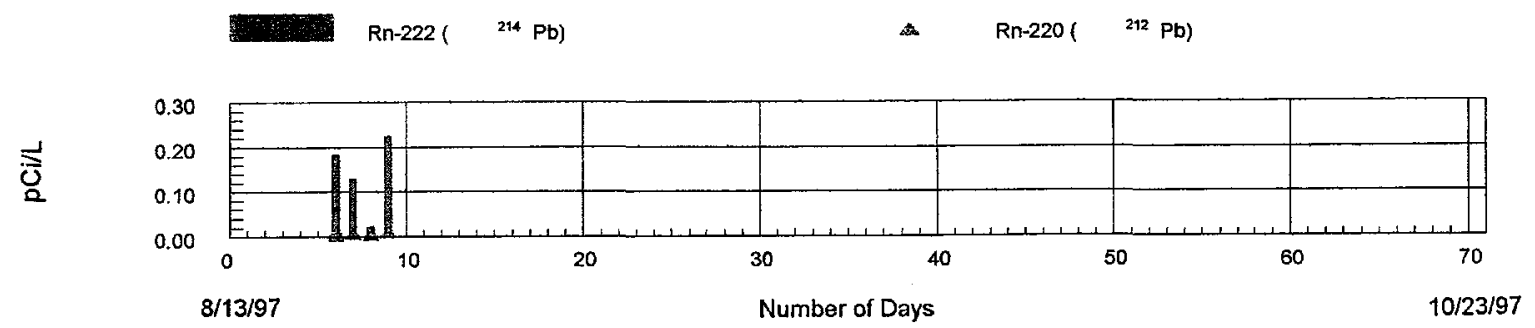

Fig. 2. Concentrations of primary radon progeny measured at locations BP1 and BP2. 


\section{Location BP3: NE Corner of Bay}

$\mathrm{Rn}-222\left({ }^{214} \mathrm{~Pb}\right)$

A Rn-220 ( ${ }^{212} \mathrm{~Pb}$ )

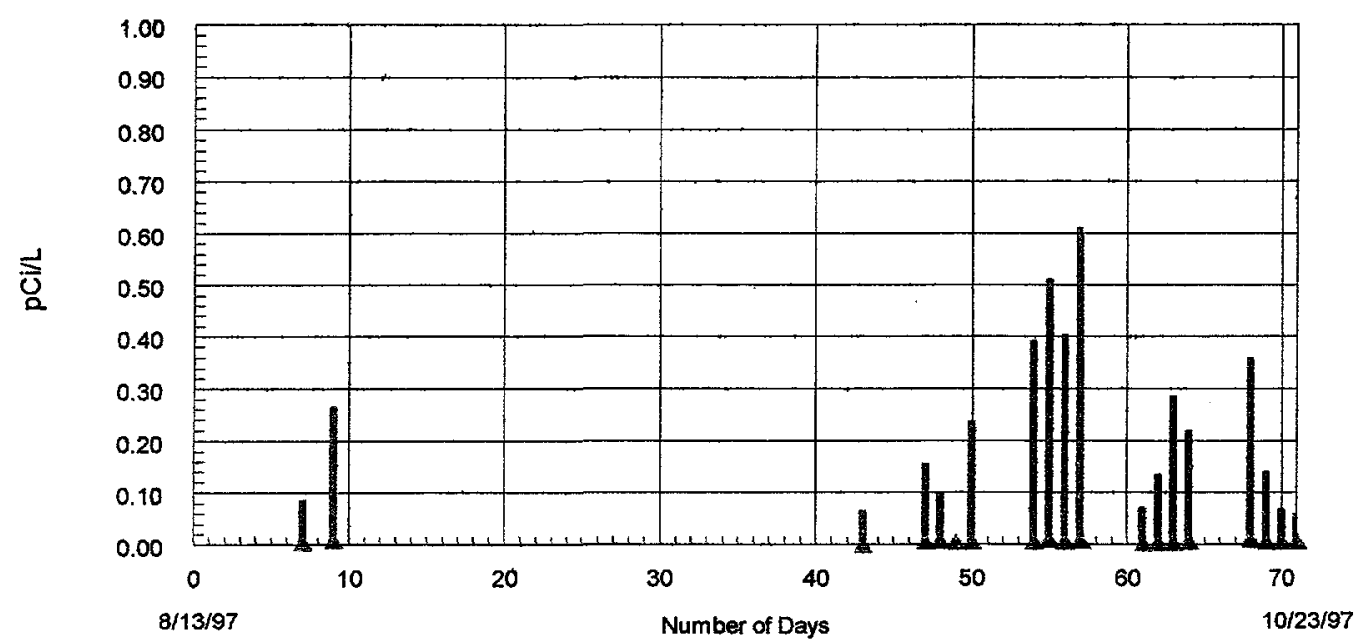

Location BP4: Equipment Storage Pit

$\mathrm{Rn}-222\left({ }^{214} \mathrm{~Pb}\right) \quad \mathrm{Rn}-220\left({ }^{212} \mathrm{~Pb}\right)$

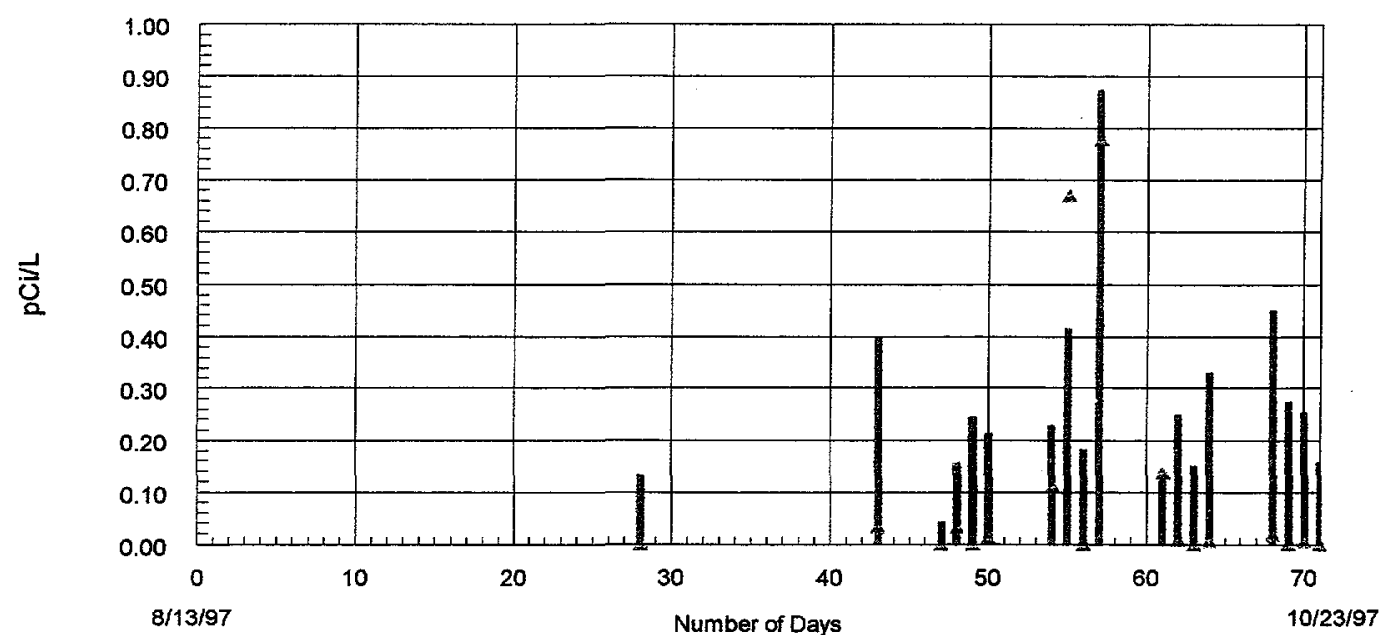

Fig. 3. Concentrations of primary radon progeny measured at locations BP3 and BP4. 


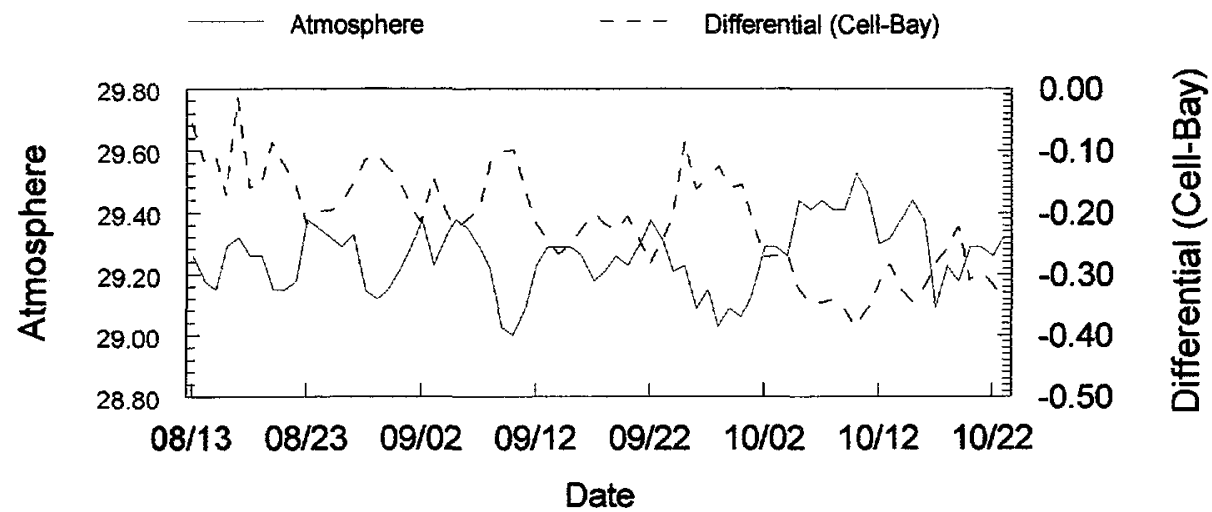

Fig. 4. Plot of daily atmospheric pressure and of the differential pressure between the high bay and equipment cell (e.g., the cell pressure minus the high bay pressure). 
Th-B Error Plot

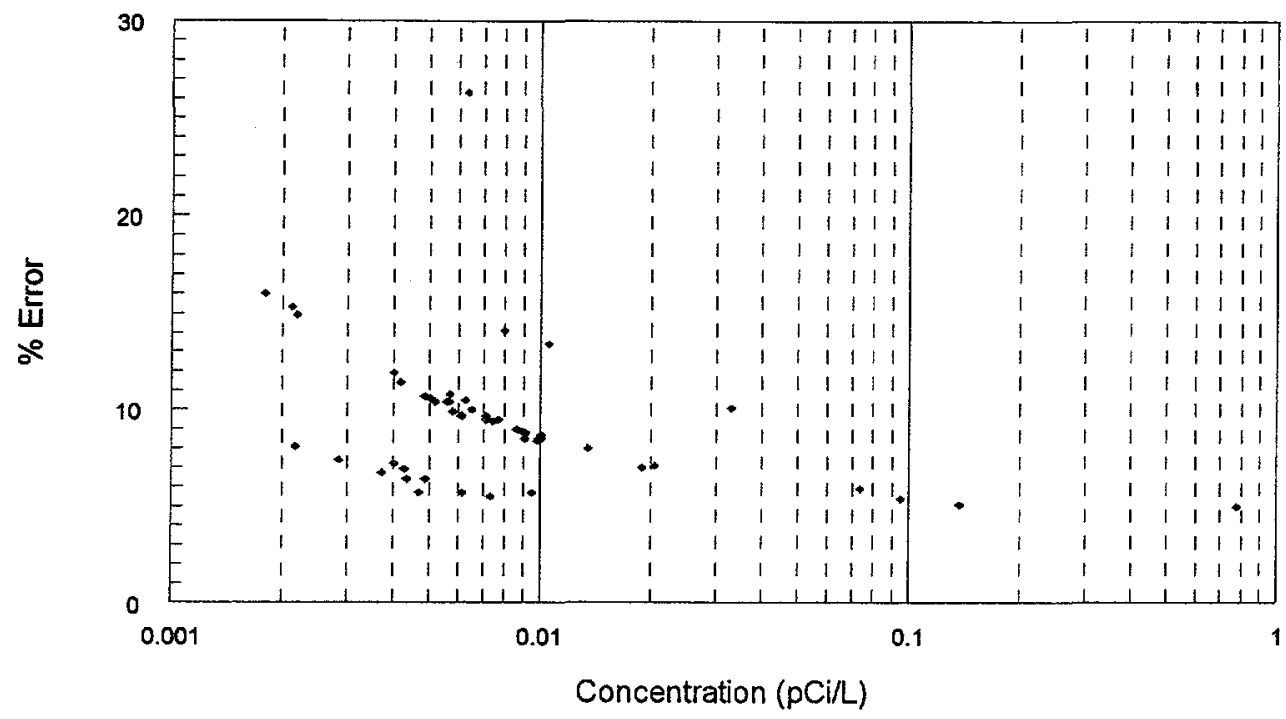

Th-C Error Plot

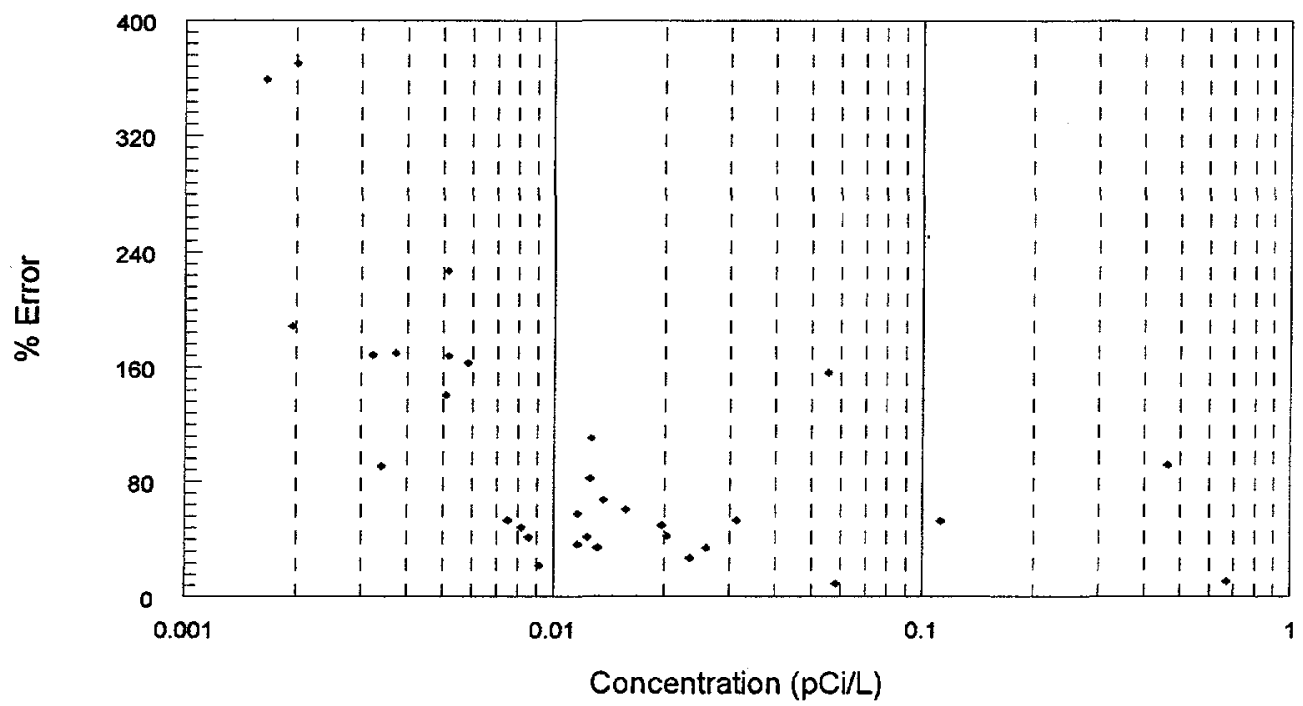

Fig. 5. Plot of percent standard measurement error (67\% confidence) versus measured concentration for ${ }^{212} \mathrm{~Pb}$ and ${ }^{212} \mathrm{Bi}$ (Th-B and $\mathrm{Th}-\mathrm{C}$ ). 
Ra-A Error Plot

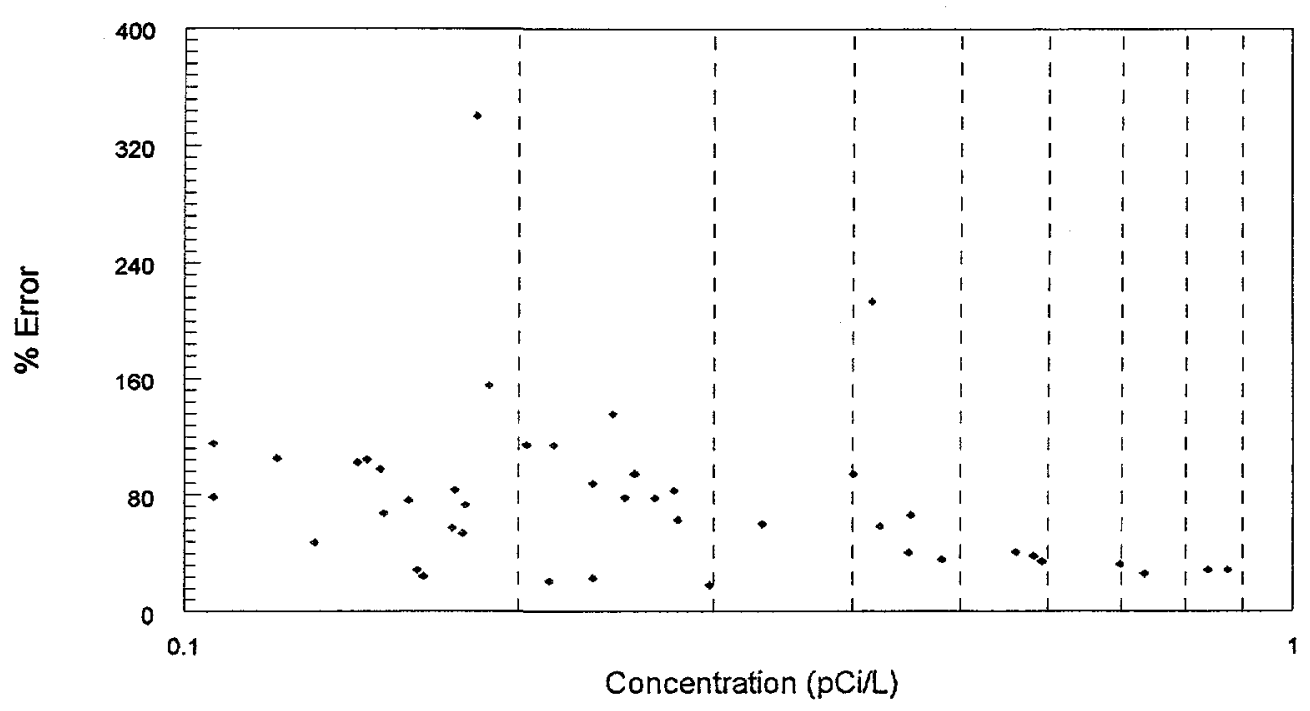

\section{Ra-B Error Plot}

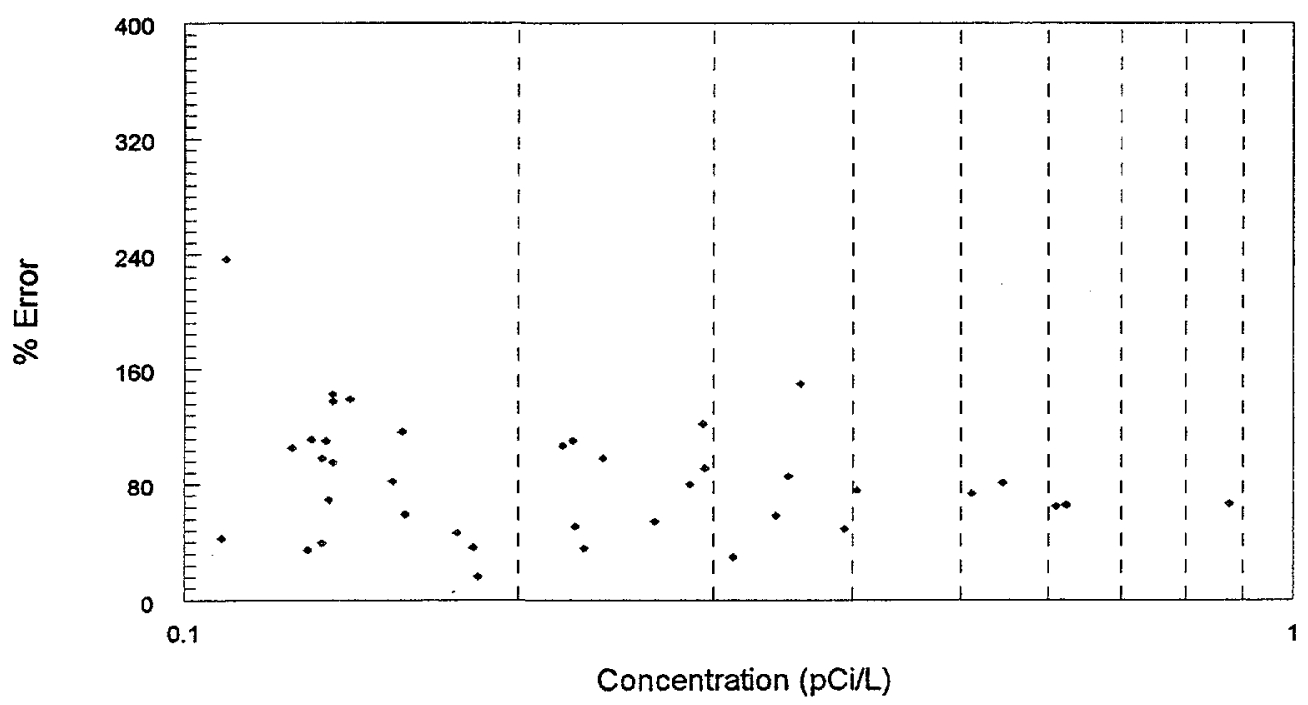

Fig. 6. Plot of percent standard measurement error (67\% confidence) versus measured concentration for ${ }^{218} \mathrm{Po}$ and ${ }^{214} \mathrm{~Pb}$ (Ra-A and $\left.\mathrm{Ra}-\mathrm{B}\right)$. 
November 1997

Pit above the Drain Tank Cell in Building 7503 High Bay

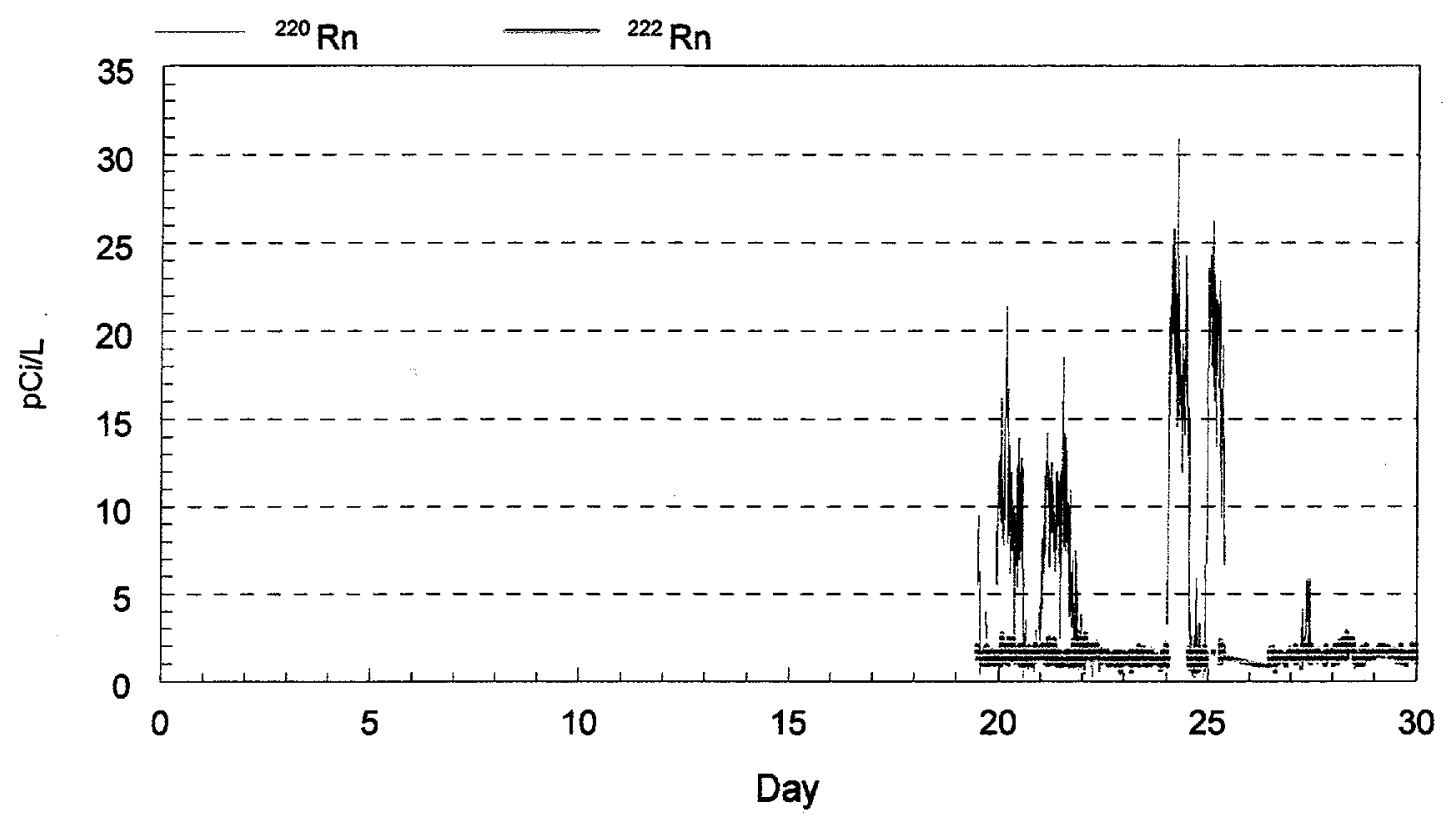

December 1997

Pit above the Drain Tank Cell in Building 7503 High Bay

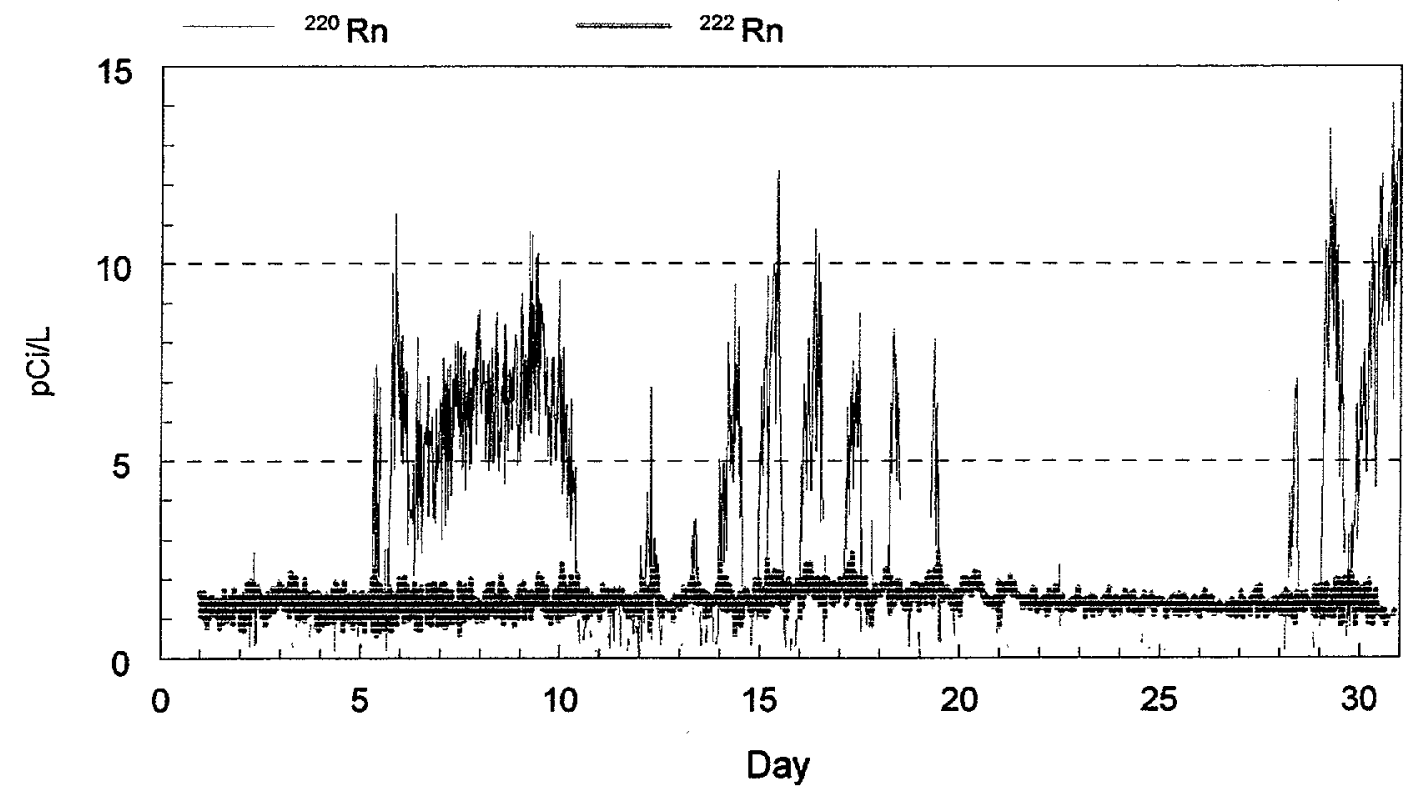

Fig. 7. Radon measurements in the pit above the equipment drain tank cell during November and December 1997. 
January 1998

Pit above Drain Tank Cell in Building 7503 High Bay

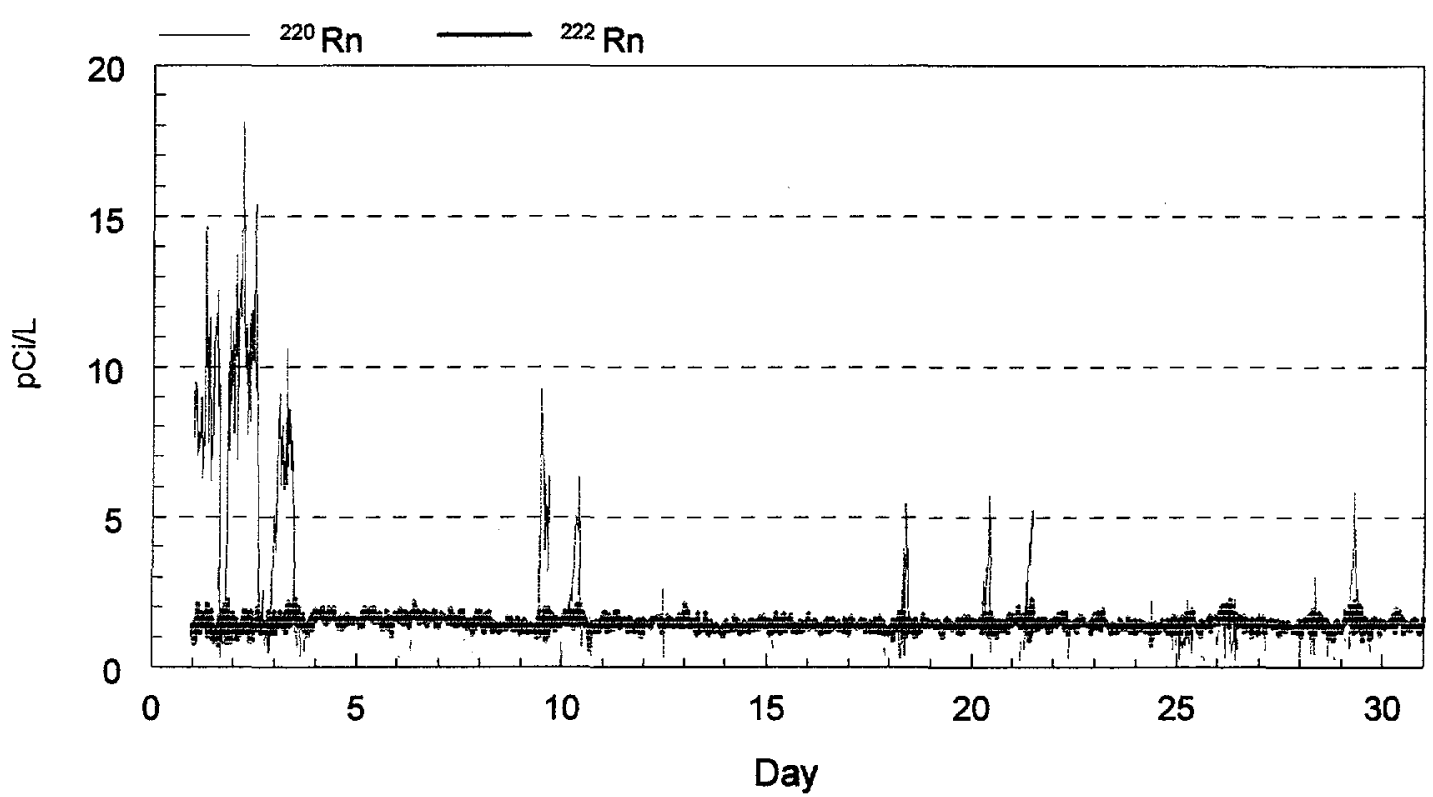

February 1998

Pit Above Drain Tank Cell in Building 7503 High Bay

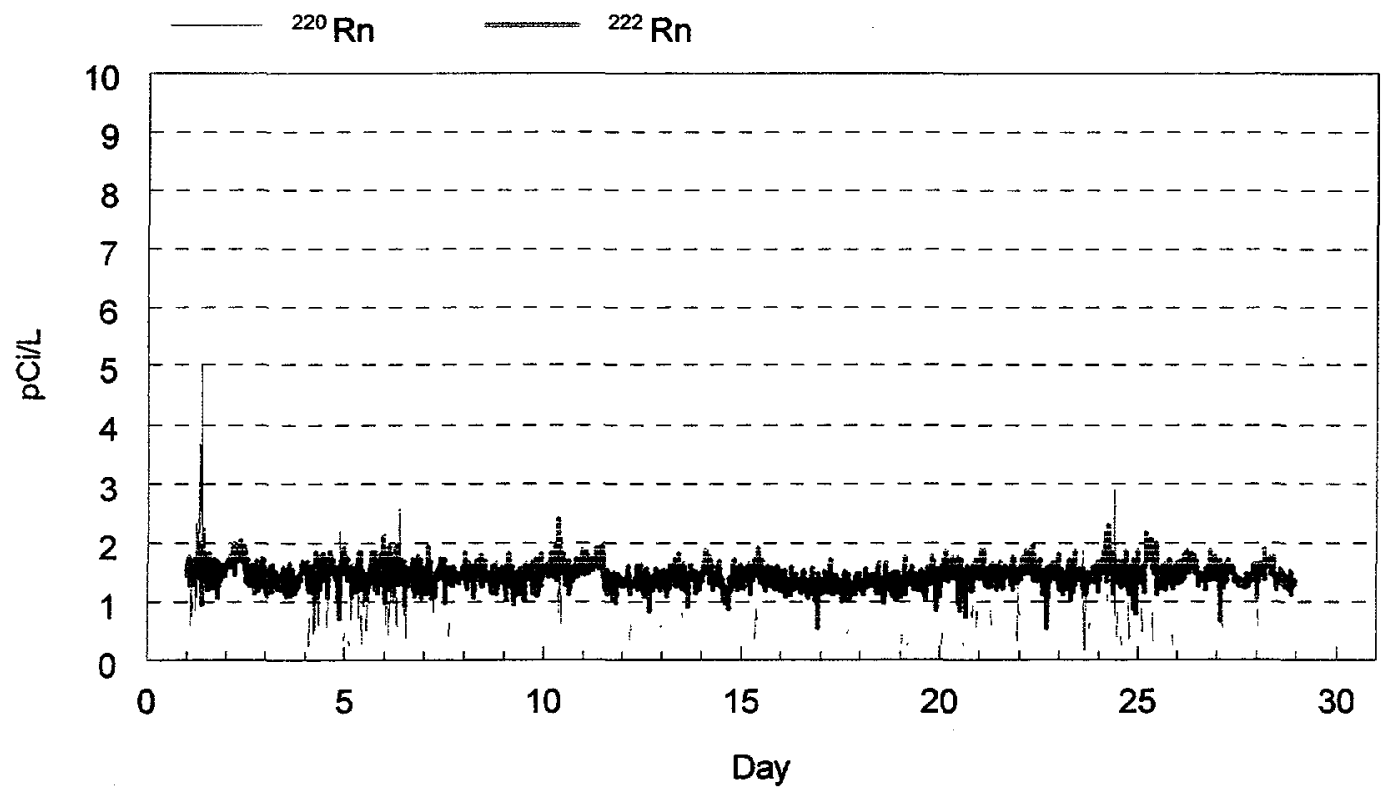

Fig. 8. Radon measurements in the pit above the equipment drain tank cell during January and February 1998. 


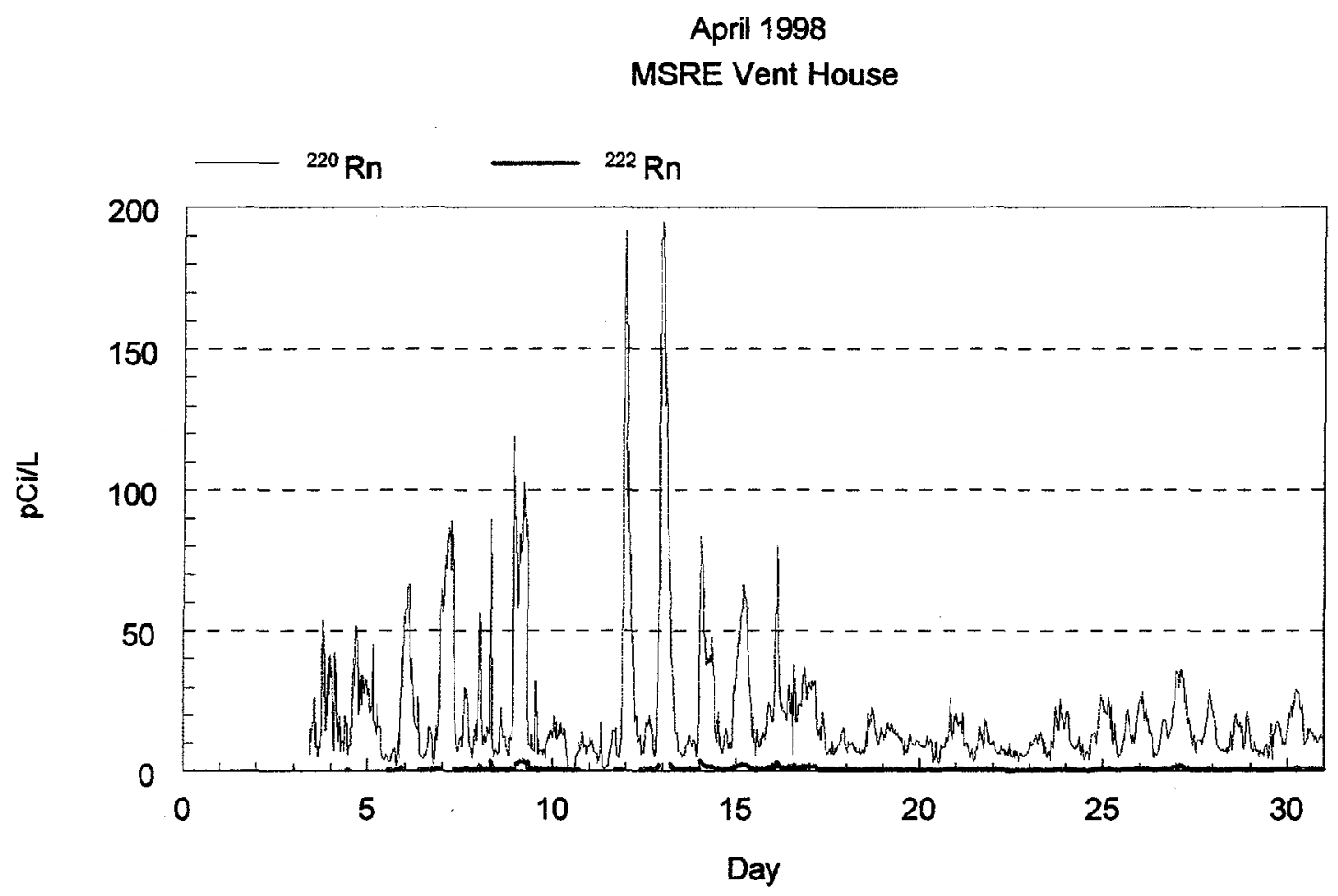

Fig. 9. Radon measurements in the vent house during April 1998. 


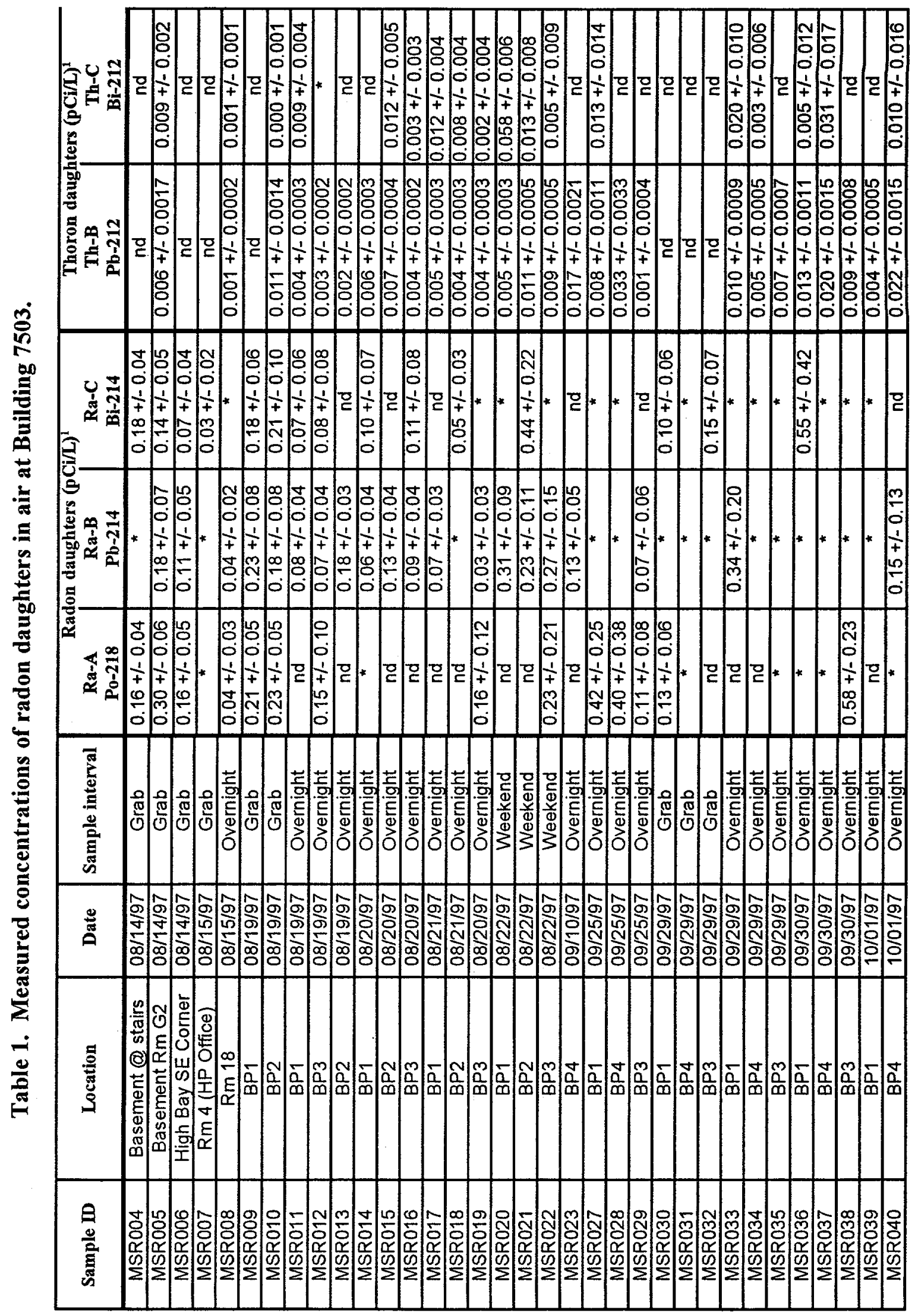


Table 1 (continued)

\begin{tabular}{|c|c|c|c|c|c|c|c|c|}
\hline \multirow[b]{2}{*}{ Sample ID } & \multirow[b]{2}{*}{ Location } & \multirow[b]{2}{*}{ Date } & \multirow[b]{2}{*}{ Sample interval } & \multicolumn{3}{|c|}{ Radon daughters (pCi/L) } & \multicolumn{2}{|c|}{ Thoron daughters $(\mathrm{pCi} / \mathrm{L})^{1}$} \\
\hline & & & & $\begin{array}{l}\text { Ra-A } \\
\text { Po-218 }\end{array}$ & $\begin{array}{c}\text { Ra-B } \\
\text { Pb-214 }\end{array}$ & $\begin{array}{c}\text { Ra-C } \\
\text { Bi-214 }\end{array}$ & $\begin{array}{c}\text { Th-B } \\
\text { Pb-212 }\end{array}$ & $\begin{array}{c}\text { Th-C } \\
\text { Bi-212 }\end{array}$ \\
\hline MSR041 & $\mathrm{BP3}$ & $10 / 01 / 97$ & Overnight & $0.18+/-0.15$ & nd & $0.55+/-0.28$ & $0.006+1-0.0006$ & nd \\
\hline MSR042 & BP1 & $10 / 02 / 97$ & Overnight & \# & $0.29+1-0.27$ & $\hbar$ & $0.007+1-0.0007$ & $0.026+1-0.009$ \\
\hline MSR043 & $\mathrm{BP4}$ & $10 / 02 / 97$ & Overnight & * & $0.14+/-0.09$ & nd & $0.009+1-0.0008$ & $0.013+1-0.010$ \\
\hline MSR044 & $\mathrm{BP3}$ & $10 / 02 / 97$ & Overnight & $0.28+1-0.23$ & $0.24+/-0.24$ & * & $0.008+1-0.0007$ & $0.016+1-0.009$ \\
\hline MSR045 & $\mathrm{BP1}$ & $10 / 06 / 97$ & Overnight & $\star$ & $\star$ & * & $0.004+1-0.0004$ & nd \\
\hline MSR046 & BP4 & $10 / 06 / 97$ & Overnight & nd & $\overline{7}$ & $\hbar$ & $0.073+1-0.0043$ & $0.112+1-0.060$ \\
\hline MSR047 & $\mathrm{BP3}$ & $10 / 06 / 97$ & Overnight & $\hbar$ & $0.39+1-0.20$ & nd & $0.006+1-0.0006$ & $0.020+1-0.009$ \\
\hline MSR048 & $\mathrm{BP1}$ & $10 / 07 / 97$ & Overnight & $0.56+1-0.23$ & $0.62+/-0.41$ & $\hbar$ & $0.010+/-0.0008$ & nd \\
\hline MSR049 & BP4 & $10 / 07 / 97$ & Overnight & * & $\bar{k}$ & $\hbar$ & $0.095+1-0.0051$ & $0.670+1-0.079$ \\
\hline MSR050 & $\mathrm{BP3}$ & $10 / 07 / 97$ & Overnight & $0.25+1-0.24$ & $0.51+/-0.38$ & $\overline{7}$ & $0.010+1-0.0008$ & $0.014+1-0.009$ \\
\hline MSR051 & $\mathrm{BP} 1$ & $10 / 08 / 97$ & Overnight & $0.84+1-0.25$ & $0.35+1-0.30$ & $\hbar$ & $0.007+/-0.0007$ & nd \\
\hline MSR052 & BP4 & $10 / 08 / 97$ & Overnight & $\pi$ & 7 & nd & $0.075+/-0.0042$ & $0.082+1-0.047$ \\
\hline MSR053 & $\mathrm{BP3}$ & $10 / 08 / 97$ & Overnight & $0.70+1-0.23$ & $0.40+/-0.31$ & $\pi$ & $0.007+/-0.0007$ & $\hbar$ \\
\hline MSR054 & $\mathrm{BP1}$ & $10 / 09 / 97$ & Overnight & $\hbar$ & $\star$ & \# & $0.003+1-0.0004$ & nd \\
\hline MSR055 & $\mathrm{BP4}$ & $10 / 09 / 97$ & Overnight & * & $0.88+/-0.59$ & 7 & $0.778+1-0.0389$ & $0.464+/-0.429$ \\
\hline MSR056 & $\mathrm{BP3}$ & $10 / 09 / 97$ & Overnight & $0.27+1-0.21$ & $0.61+1-0.40$ & ћ & $0.009+/-0.0008$ & nd \\
\hline MSR057 & $\mathrm{BP1}$ & $10 / 13 / 97$ & Overnight & * & $\star$ & \# & $0.002+/-0.0003$ & * \\
\hline MSR058 & $\mathrm{BP4}$ & $10 / 13 / 97$ & Overnight & nd & * & $0.13+/-0.13$ & $0.137+/-0.0070$ & $0.055+/ .0 .087$ \\
\hline MSR059 & $\mathrm{BP3}$ & $10 / 13 / 97$ & Overnight & nd & $\star$ & $\bar{t}$ & $0.002+7-0.0003$ & $0.013+1-0.005$ \\
\hline MSR060 & BP1 & $10 / 14 / 97$ & Overnight & nd & $0.10+/-0.09$ & $\hbar$ & $0.001+1-0.0002$ & 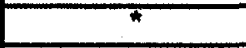 \\
\hline MSR061 & BP4 & $10 / 14 / 97$ & Overnight & $0.25+1-0.20$ & $0.14+1-0.13$ & $\bar{\hbar}$ & $0.009+1-0.0008$ & nd \\
\hline MSR062 & $\mathrm{BP3}$ & $10 / 14 / 97$ & Overnight & * & $\star$ & $\bar{\hbar}$ & $0.004+1-0.0005$ & nd \\
\hline MSR063 & BP1 & $10 / 15 / 97$ & Overnight & $0.18+1-0.13$ & 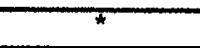 & * & $0.002+1-0.0003$ & $0.007+1-0.004$ \\
\hline MSR064 & BP4 & $10 / 15 / 97$ & Overnight & $0.15+1-0.15$ & * & nd & $0.005+1-0.0005$ & nd \\
\hline MSR065 & $\mathrm{BP3}$ & $10 / 15 / 97$ & Overnight & * & $0.29+1-0.23$ & 7 & $0.004+/-0.0005$ & $0.023+1-0.006$ \\
\hline MSR066 & $\mathrm{BP1}$ & $10 / 16 / 97$ & Overnight & $0.17+/-0.10$ & nd & $0.14+/-0.14$ & $0.001+1-0.0002$ & $0.002+1-0.002$ \\
\hline MSR067 & BP4 & $10 / 16 / 97$ & Overnight & $0.33+1-0.20$ & nd & * & $0.006+1-0.0006$ & nd \\
\hline MSR068 & $\mathrm{BP3}$ & $10 / 16 / 97$ & Overnight & $0.45+1-0.19$ & \# & $\overline{7}$ & $0.005+1-0.0005$ & nd \\
\hline MSR069 & $\mathrm{BP1}$ & $10 / 20 / 97$ & Overnight & $0.87+1-0.26$ & $0.55+/-0.44$ & 屯 & $0.006+1-0.0006$ & $0.012+1-0.007$ \\
\hline MSR070 & BP4 & $10 / 20 / 97$ & Overnight & $0.45+1-0.30$ & * & $\hbar$ & $0.019+/-0.0013$ & nd \\
\hline MSR071 & $\mathrm{BP3}$ & $10 / 20 / 97$ & Overnight & $1.01+/-0.28$ & * & $\overline{-}$ & $0.010+1-0.0009$ & $0.006+1-0.009$ \\
\hline MSR072 & $\mathrm{BP1}$ & $10 / 21 / 97$ & Overnight & $0.18+1-0.10$ & $0.13+1-0.13$ & nd & $0.002+1-0.0003$ & nd \\
\hline MSR073 & $\mathrm{BP4}$ & $10 / 21 / 97$ & Overnight & & nd & $0.28+1-0.19$ & $0.008+1-0.0007$ & nd \\
\hline MSR074 & $\mathrm{BP3}$ & $10 / 21 / 97$ & Overnight & $0.28+1-0.18$ & * & & $0.005+1-0.0005$ & $0.004+1-0.006$ \\
\hline
\end{tabular}


Table 1 (continued)

\begin{tabular}{|c|c|c|c|c|c|c|c|c|}
\hline \multirow[b]{2}{*}{ Sample ID } & \multirow[b]{2}{*}{ Location } & \multirow[b]{2}{*}{ Date } & \multirow[b]{2}{*}{ Sample interval } & \multicolumn{3}{|c|}{ Radon daughters (pCi/L) } & \multicolumn{2}{|c|}{ Thoron daughters $(\mathrm{pCi} / \mathrm{L})^{1}$} \\
\hline & & & & $\begin{array}{c}\text { Ra-A } \\
\text { Po-218 }\end{array}$ & $\begin{array}{c}\text { Ra-B } \\
\text { Pb-214 }\end{array}$ & $\begin{array}{l}\text { Ra-C } \\
\text { Bi-214 }\end{array}$ & $\begin{array}{c}\text { Th-B } \\
\mathbf{P b}-\mathbf{2 1 2}\end{array}$ & $\begin{array}{c}\text { Th-C } \\
\text { Bi-212 }\end{array}$ \\
\hline MSR075 & $\mathrm{BP1}$ & $10 / 22 / 97$ & Overnight & $0.48+/-0.18$ & $\star$ & 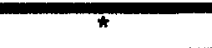 & $0.004+1-0.0005$ & $0.003+/-0.005$ \\
\hline MSR076 & $\mathrm{BP4}$ & $10 / 22 / 97$ & Overnight & * & nd & $0.26+1-0.20$ & $0.005+1-0.0005$ & 7 \\
\hline MSR077 & $\mathrm{BP3}$ & $10 / 22 / 97$ & Overnight & $0.73+1-0.20$ & * & $0.7 \cdot 1+/-0.62$ & $0.006+1-0.0006$ & nd \\
\hline MSR078 & BP1 & $10 / 23 / 97$ & Overnight & * & nd & $0.32+/-0.23$ & $0.002+1-0.0003$ & $0.002+/-0.003$ \\
\hline MSR079 & BP4 & $10 / 23 / 97$ & Overnight & nd & $0.16+1-0.09$ & nd & $0.004+1-0.0005$ & $0.013+1-0.006$ \\
\hline MSR080 & BP3 & $10 / 23 / 97$ & Overnight & $0.59+/-0.21$ & $\hbar$ & $0.72+1-0.60$ & $0.006+1-0.0007$ & $0.005+/-0.007$ \\
\hline MSR082 & $\mathrm{FH1}$ & $01 / 30 / 98$ & Overnight & $*$ & * & nd & $0.022+1-0.0013$ & $0.011+/-0.017$ \\
\hline MSR085 & FH1 & $03 / 11 / 98$ & Overnight & $0.65+1-0.60$ & nd & $\hbar$ & $0.078+1-0.0039$ & nd \\
\hline MSR087 & FH1 & $03 / 13 / 98$ & Weekend & $\star$ & nd & $0.75+1-0.43$ & $0.070+1-0.0042$ & nd \\
\hline MSR091 & FH1 & $03 / 18 / 98$ & Overnight & nd & nd & $0.16+/-0.14$ & $0.061+1-0.0036$ & nd \\
\hline MSR097 & FH1 & $03 / 18 / 98$ & Overnight & \# & nd & $0.16+/-0.11$ & $0.022+/-0.0015$ & $0.186+/-0.024$ \\
\hline MSR099 & FH1 & $03 / 18 / 98$ & Overnight & nd & 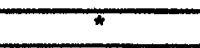 & & $0.032+1-0.0019$ & 0 \\
\hline
\end{tabular}

${ }^{1}$ The indicated relative errors are for one standard deviation (67\% confidence). Many measurements showed very low concentrations and the associated relative errors are consequently large. All measurements showing an asterisk $\left(^{*}\right)$ indicate that the relative error was greater than $100 \%$. Entries showing a measurement result of nd indicate that the isotope was either not present or could not be detected in the presence of other radionuclides. 
Table 2. Ratio of the measured radon daughter working levels to the derived air concentration (DAC) guide

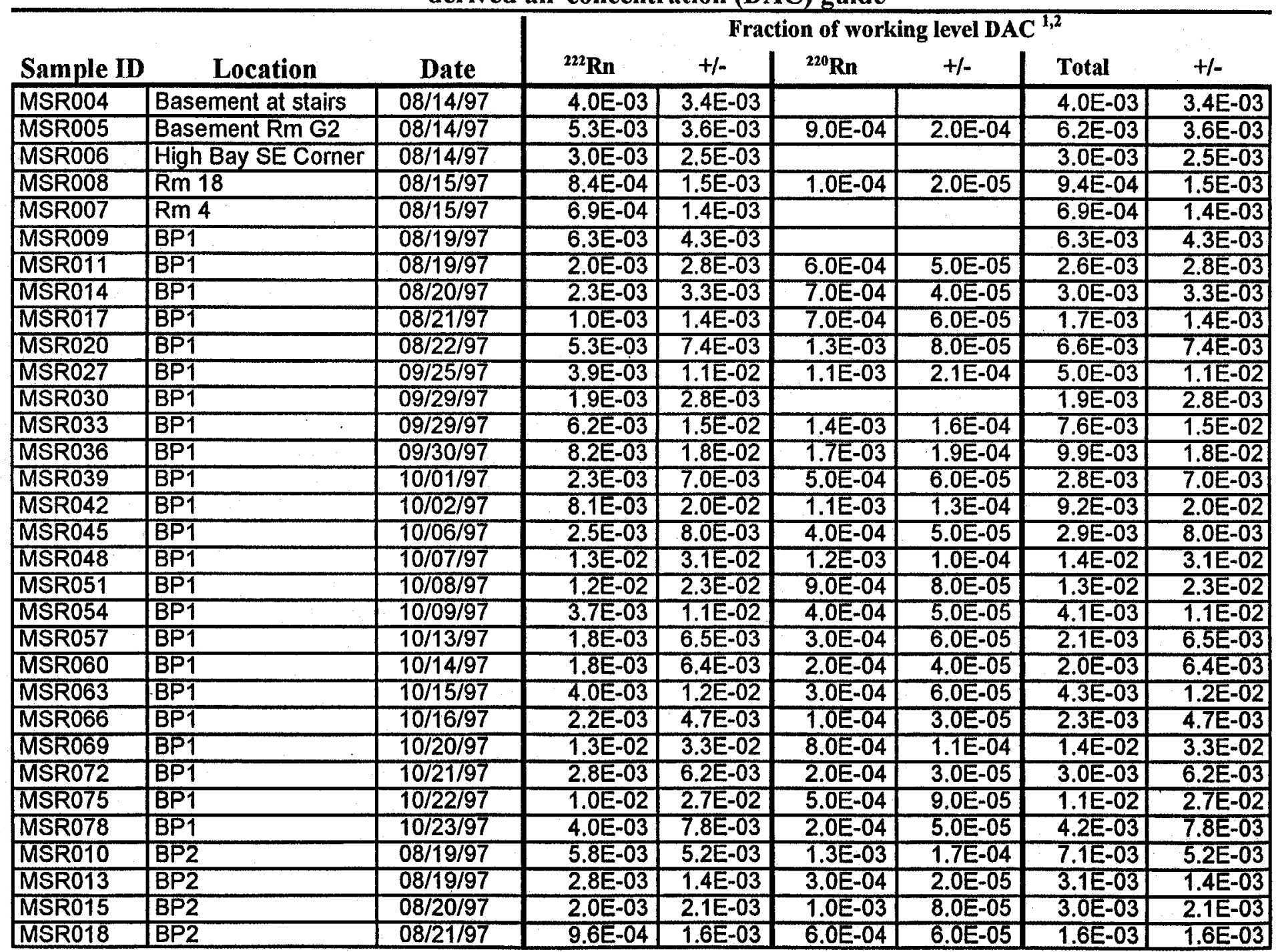


Table 2 (continued)

\begin{tabular}{|c|c|c|c|c|c|c|c|c|}
\hline \multirow[b]{2}{*}{ Sample ID } & \multirow[b]{2}{*}{ Location } & \multirow[b]{2}{*}{ Date } & \multicolumn{6}{|c|}{ Fraction of working level $\mathrm{DAC}{ }^{1,2}$} \\
\hline & & & ${ }^{222} \mathbf{R n}$ & $+1-$ & ${ }^{220} \mathbf{R n}$ & $+/-$ & Total & $+1-$ \\
\hline MSR021 & BP2 & $08 / 22 / 97$ & $8.5 \mathrm{E}-03$ & $9.3 E-03$ & $1.5 \mathrm{E}-03$ & 1.1E-04 & $1.0 \mathrm{E}-02$ & $9.3 \mathrm{E}-03$ \\
\hline MSR012 & BP3 & $08 / 19 / 97$ & $2.5 \mathrm{E}-03$ & $3.4 E-03$ & $4.0 \mathrm{E}-04$ & $4.0 \mathrm{E}-05$ & $2.9 \mathrm{E}-03$ & $3.4 \mathrm{E}-03$ \\
\hline MSR016 & BP3 & $08 / 20 / 97$ & $2.5 \mathrm{E}-03$ & $3.3 \mathrm{E}-03$ & $5.0 \mathrm{E}-04$ & $5.0 \mathrm{E}-05$ & $3.0 \mathrm{E}-03$ & $3.3 \mathrm{E}-03$ \\
\hline MSR019 & BP3 & $08 / 20 / 97$ & $1.1 \mathrm{E}-03$ & $2,2 \mathrm{E}-03$ & $5.0 \mathrm{E}-04$ & $6.0 \mathrm{E}-05$ & $1.6 \mathrm{E}-03$ & $2.2 \mathrm{E}-03$ \\
\hline MSR022 & BP3 & $08 / 22 / 97$ & $8.0 E-03$ & $1.2 \mathrm{E}-02$ & $1.2 \mathrm{E}-03$ & $1.2 \mathrm{E}-04$ & $9.2 \mathrm{E}-03$ & $1.2 \mathrm{E}-02$ \\
\hline MSR029 & BP3 & $09 / 25 / 97$ & $1.4 \mathrm{E}-03$ & $2.9 E-03$ & $2.0 \mathrm{E}-04$ & $5.0 \mathrm{E}-05$ & $1.6 \mathrm{E}-03$ & $2.9 \mathrm{E}-03$ \\
\hline MSR032 & $\overline{B P 3}$ & $09 / 29 / 97$ & $1.9 \mathrm{E}-03$ & $3.0 \mathrm{E}-03$ & & & $1.9 \mathrm{E}-03$ & $3.0 \mathrm{E}-03$ \\
\hline MSR035 & BP3 & $09 / 29 / 97$ & $6.2 \mathrm{E}-03$ & $1.4 \mathrm{E}-02$ & $9.0 \mathrm{E}-04$ & $8.0 \mathrm{E}-05$ & $7.1 \mathrm{E}-03$ & $1.4 \mathrm{E}-02$ \\
\hline MSR038 & BP3 & $09 / 30 / 97$ & $6.2 \mathrm{E}-03$ & $1.3 \mathrm{E}-02$ & $1.1 E-03$ & $1.0 \mathrm{E}-04$ & $7.3 \mathrm{E}-03$ & $1.3 E-02$ \\
\hline MSR041 & BP3 & $10 / 01 / 97$ & $6.8 \mathrm{E}-03$ & $9.7 \mathrm{E}-03$ & $7.0 \mathrm{E}-04$ & $7.0 \mathrm{E}-05$ & $7.5 \mathrm{E}-03$ & $9.7 \mathrm{E}-03$ \\
\hline MSR044 & $\overline{B P 3}$ & $10 / 02 / 97$ & $7.2 E-03$ & $1.8 E-02$ & 1.1E-03 & $1.4 E-04$ & $8.3 E-03$ & $1.8 \mathrm{E}-02$ \\
\hline MSR047 & BP3 & $10 / 06 / 97$ & $6.3 E-03$ & $9.3 \mathrm{E}-03$ & $9.0 \mathrm{E}-04$ & $1.3 \mathrm{E}-04$ & $7.2 \mathrm{E}-03$ & $9.3 \mathrm{E}-03$ \\
\hline MSR050 & BP3 & $10 / 07 / 97$ & $1.2 \mathrm{E}-02$ & $2.9 \mathrm{E}-02$ & $1.4 \mathrm{E}-03$ & $1.5 \mathrm{E}-04$ & $1.3 \mathrm{E}-02$ & $2.9 \mathrm{E}-02$ \\
\hline MSR053 & BP3 & $10 / 08 / 97$ & $1.1 \mathrm{E}-02$ & $2.3 E-02$ & $9.0 \mathrm{E}-04$ & $1.2 \mathrm{E}-04$ & $1.2 \mathrm{E}-02$ & $2.3 \mathrm{E}-02$ \\
\hline MSR056 & $\overline{B P 3}$ & $10 / 09 / 97$ & $1.2 \mathrm{E}-02$ & $3.0 \mathrm{E}-02$ & $1.0 \mathrm{E}-03$ & $9.0 \mathrm{E}-05$ & $1.3 \mathrm{E}-02$ & $3.0 \mathrm{E}-02$ \\
\hline MSR059 & BP3 & $10 / 13 / 97$ & $1.7 \mathrm{E}-03$ & $7.1 \mathrm{E}-03$ & $4.0 \mathrm{E}-04$ & 7.0 E-05 & $2.1 E-03$ & $7.1 \mathrm{E}-03$ \\
\hline MSR062 & $\overline{8 P 3}$ & $10 / 14 / 97$ & $5.8 \mathrm{E}-03$ & $1.5 \mathrm{E}-02$ & $5.0 \mathrm{E}-04$ & $6.0 \mathrm{E}-05$ & $6.3 \mathrm{E}-03$ & $1.5 \mathrm{E}-02$ \\
\hline MSR065 & $\mathrm{BP3}$ & $10 / 15 / 97$ & $5.5 \mathrm{E}-03$ & 1.7E-02 & 8.0E-04 & $1.0 \mathrm{E}-04$ & $6.3 \mathrm{E}-03$ & 1.7E-02 \\
\hline MSR068 & $\overline{B P 3}$ & $10 / 16 / 97$ & $5.9 \mathrm{E}-03$ & $1.8 \mathrm{E}-02$ & $6.0 \mathrm{E}-04$ & $6.0 \mathrm{E}-05$ & $6.5 \mathrm{E}-03$ & $1.8 \mathrm{E}-02$ \\
\hline MSR071 & $\overline{B P 3}$ & $10 / 20 / 97$ & $1.6 \mathrm{E}-02$ & $4.0 \mathrm{E}-02$ & $1.3 E-03$ & $1.5 E-04$ & 1.7E-02 & $4.0 E-02$ \\
\hline MSR074 & BP3 & $10 / 21 / 97$ & $6.2 \mathrm{E}-03$ & $1.5 \mathrm{E}-02$ & $6.0 \mathrm{E}-04$ & $1.0 \mathrm{E}-04$ & $6.8 \mathrm{E}-03$ & $1.5 \mathrm{E}-02$ \\
\hline MSR077 & $\overline{B P 3}$ & $10 / 22 / 97$ & 1.1E-02 & $2.7 E-02$ & $7.0 \mathrm{E}-04$ & $7.0 \mathrm{E}-05$ & $1.2 \mathrm{E}-02$ & $2.7 \mathrm{E}-02$ \\
\hline MSR080 & $\overline{\mathrm{BP3}}$ & $10 / 23 / 97$ & $1.1 \mathrm{E}-02$ & $2.6 \mathrm{E}-02$ & $8.0 \mathrm{E}-04$ & $1.2 E-04$ & $1.2 \mathrm{E}-02$ & $2.6 \mathrm{E}-02$ \\
\hline MSR023 & $\overline{\mathrm{BP4}}$ & $09 / 10 / 97$ & $2.1 E-03$ & $2.4 E-03$ & $2.1 E-03$ & $2.5 \mathrm{E}-04$ & $4.2 \mathrm{E}-03$ & $2.4 \mathrm{E}-03$ \\
\hline MSR028 & $\overline{B P 4}$ & $09 / 25 / 97$ & $5.4 \mathrm{E}-03$ & 1.1E-02 & $4.0 \mathrm{E}-03$ & $4.0 \mathrm{E}-04$ & $9.4 \mathrm{E}-03$ & 1.1E-02 \\
\hline MSR031 & BP4 & $09 / 29 / 97$ & $4.8 \mathrm{E}-04$ & $1.4 E-03$ & & & $4.8 E-04$ & 1.4E-03 \\
\hline MSR034 & BP4 & $09 / 29 / 97$ & $8.6 \mathrm{E}-04$ & $3.1 \mathrm{E}-03$ & $6.0 \mathrm{E}-04$ & $9.0 \mathrm{E}-05$ & $1.5 E-03$ & $3.1 \mathrm{E}-03$ \\
\hline MSR037 & $\overline{B P 4}$ & $09 / 30 / 97$ & $2.9 \mathrm{E}-03$ & $8.3 \mathrm{E}-03$ & $2.8 \mathrm{E}-03$ & 2.7E-04 & $5.7 E-03$ & $8.3 \mathrm{E}-03$ \\
\hline MSR040 & $\mathrm{BP4}$ & $10 / 01 / 97$ & 3.1E-03 & 6.7E-03 & $2.8 \mathrm{E}-03$ & 2.6E-04 & $5.9 E-03$ & $6.7 E_{-03}$ \\
\hline MSR043 & BP4 & $10 / 02 / 97$ & $2.8 \mathrm{E}-03$ & $4.9 \mathrm{E}-03$ & $1.2 \mathrm{E}-03$ & $1.6 \mathrm{E}-04$ & $4.0 \mathrm{E}-03$ & $4.9 \mathrm{E}-03$ \\
\hline MSR046 & BP4 & $10 / 06 / 97$ & $4.7 E-03$ & $1.3 \mathrm{E}-02$ & $1.0 \mathrm{E}-02$ & $8.9 E-04$ & 1.5E-02 & $1.3 \mathrm{E}-02$ \\
\hline MSR049 & BP4 & $10 / 07 / 97$ & $6.8 E-03$ & $1.9 E-02$ & $2.0 \mathrm{E}-02$ & 1.1E-03 & $2.6 \mathrm{E}-02$ & $1.9 \mathrm{E}-02$ \\
\hline MSR052 & $\overline{B P 4}$ & $10 / 08 / 97$ & $2.5 \mathrm{E}-03$ & $8.5 \mathrm{E}-03$ & $1.0 \mathrm{E}-02$ & $7.6 \mathrm{E}-04$ & 1.3E-02 & $8.5 \mathrm{E}-03$ \\
\hline
\end{tabular}


Table 2 (continued)

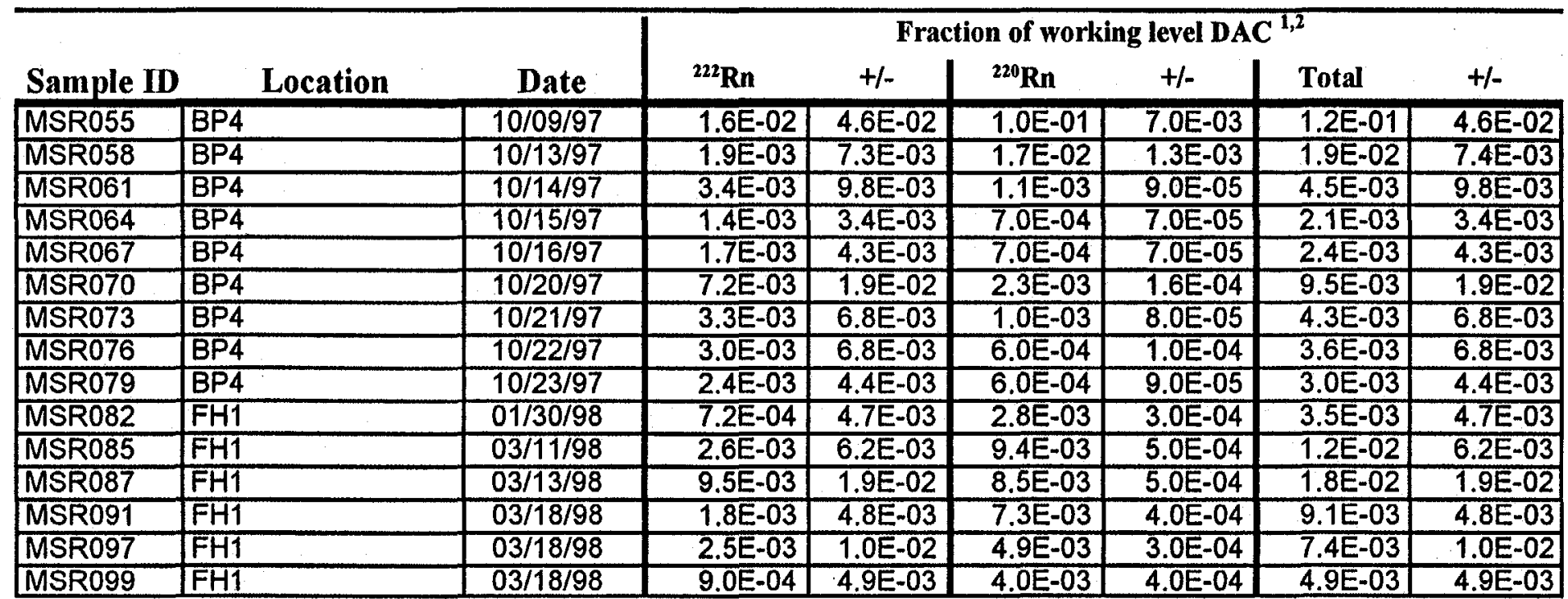

'The daughter measurement results have been divided by the DAC working level limits listed by DOE in 10 CFR 835 (DOE 1993) for continuous occupational exposure. The limits are given as $1 / 3 \mathrm{WL}$ for ${ }^{222} \mathrm{Rn}$ progeny and $1 \mathrm{WL}$ for ${ }^{220} \mathrm{Rn}$ progeny.

${ }^{2}$ The indicated relative errors are for one standard deviation ( $67 \%$ confidence). Note that most samples were collected overnight so that the measurement of ${ }^{220} \mathrm{R}$ daughters could be performed with a low amount of uncertainty. The trade-off of this method, as discussed in Section 4 , is that the ${ }^{222} \mathrm{Rn}$ daughter measurements have a high level of associated uncertainty. The uncertainty in the summed ratios, listed under the column titled "Total," accounts for measurement errors from both radon chains and therefore shows a level of uncertainty similar to that of the ${ }^{222} \mathrm{Rn}$ daughter measurements. 
Table 3. Summary of radon and thoron progeny measurements at the MSRE facility

(fraction of a working level DAC')

\begin{tabular}{|l|c|c|c|c|c|c|}
\hline \multirow{2}{*}{ Location $^{2}$} & \multicolumn{2}{|c|}{${ }^{222} \mathrm{Rn}$} & \multicolumn{2}{c|}{${ }^{220} \mathrm{Rn}$} & \multicolumn{2}{c|}{ Total } \\
\cline { 2 - 7 } & Maximum & Average & Maximum & Average & Maximum & Average \\
\hline BP1 & 0.013 & 0.005 & 0.002 & 0.001 & 0.014 & 0.006 \\
\hline BP2 & 0.008 & 0.004 & 0.001 & 0.001 & 0.010 & 0.005 \\
\hline BP3 & 0.016 & 0.007 & 0.001 & 0.001 & 0.017 & 0.007 \\
\hline BP4 & 0.016 & 0.004 & 0.100 & 0.009 & 0.12 & 0.013 \\
\hline FH1 & 0.010 & 0.003 & 0.009 & 0.006 & 0.018 & 0.009 \\
\hline
\end{tabular}

'The daughter measurement results have been divided by the derived air concentration (DAC) working level limits listed by DOE in $10 \mathrm{CFR} 835$ (DOE 1993) for continuous occupational exposure. The limits are given as $1 / 3 \mathrm{WL}$ for ${ }^{222} \mathrm{Rn}$ progeny and $1 \mathrm{WL}$ for ${ }^{220} \mathrm{Rn}$ progeny.

${ }^{2} \mathrm{BP}=$ bay area, $\mathrm{FH}=$ vent house. 


\section{INTERNAL DISTRIBUTION}

1. S. N. Burman

2. S. G. Coffey

3-4. R. L. Coleman

5. G. R. Eidam

6. R. L. Faulkner

7. R. D. Foley

8. M. H. Haghighi

9 A. P. Kelsey

10. G. T. Mei

11. M. E. Murray
12. F. J. Peretz

13. J. E. Rushton

14. R. E. Swaja

15. R. M. Szozda

16. M. S. Uziel

17. J. L. Westbrook

18. MAD Records Center

19. ER Document Mgt. Center

20. Central Research Library

21. Laboratory Records - RC

\section{EXTERNAL DISTRIBUTION}

22-23. Office of Scientific and Technical Information, U.S. Department of Energy, P.O. Box 62, Oak Ridge, TN 37831 